\title{
Diversity and Community Structure of Plants in Selected Areas within Lake Mainit Watershed
}

\author{
Romana M.Maglinte ${ }^{1}$, Julie E.Asubar ${ }^{2}$, Emeliano M. Bermudez, Jr. ${ }^{3}$, Gregorio Z.Gamboa, $\mathrm{Jr}^{4}$., \\ Bernadette P.Bagaipo ${ }^{5}$, Archie A. Along ${ }^{6}$ and ${ }^{7}$ Edilmar P. Masuhay \\ ${ }^{1,2,3,4}$ Surigao State College of Technology - Mainit Campus, Magpayang, Mainit, Surigao del Norte \\ ${ }^{5 \& 62}$ Department of Biology, College of Arts and Sciences, Caraga State University, Ampayon, Butuan City
}

\begin{abstract}
Lake Mainit is one of the key biodiversity areas in the country, its watershed area is a habitat of endemic and native plant species but is now threatened due to anthropogenic activities such as mining, kaingin and expansion of agriculture. This study assessed the diversity and community structure of plants in the lowland and upland of the two selected areas (Cantugas and Jabonga) of Lake Mainit watershed through a transect and quadrat method. A total of 321 floral species were identified distributed into 85 families. The taxonomically well distributed families were Arecaceae, Moraceae and Fabaceae with 18, 17 and 14 species respectively and most species were trees and shrubs (187 species). The highest species diversity, richness and abundance was observed in the lowland of Jabonga while the highest dominance was observed in the upland of Catugas. The floral species of Lake Mainit watershed are threatened by anthropogenic activities especially expansion of agriculture and tree felling for infrastructure developments regardless of their environmental roles and inherent benefits. Therefore, sustainable conservation efforts should be geared towards ensuring their continuous existence in order to maintain environmental integrity.
\end{abstract}

Keywords:- Diversity, Community Structure, Lake Mainit.

\section{INTRODUCTION}

Lake Mainit is considerably the most important ecosystem in the Philippines given its diverse potentials for food and habitat requirements of various flora and fauna. Covering approximately 17,340 hectares, Lake Mainit is the fourth largest lake in the Philippines. The shores of the lake are being shared by the provinces of Surigao del Norte and Agusan del Norte which stretched an approximate total of $62.10 \mathrm{~km}$ (Lake Mainit Development Alliance Environmental Management Plan 2014).

Lake Mainit watershed is blessed with bountiful resources in both upland and lake ecosystems as shown in researches and studies conducted by various institutions (Gracia, 1981) as cited by Demetillo, et al, 2016. However, these data need to be monitored and reassessed due to the most likely occurrence of degradation because of human activities and a continuing decline in the amount of agricultural land per person which led to indiscriminate exploitation of natural resources particularly by the upland population in developing countries (Mahtab and Karim, 1992). As a result of increasing demand for firewood, timber, pasture, shelter and food crops, natural land covers, particularly tropical forests, are being degraded or converted to cropland at an alarming rate (Hall et al., 1993).

Moreover, assessment and validation of these data are imperative as the ecosystem is rapidly degrading as manifested by the recent occurrence of typhoon Basyang which brought about flash floods and a huge extent of cropland and infrastructure devastated or partially destroyed and this can be attributed to declining of terrestrial vegetation. Furthermore, assessment is necessary to determine whether previously identified species can still be found thriving in their respective habitat whose results could provide baseline information for concerned governing institutions like DENR, LMDA, and other stakeholders as a basis in their future planning and possible measures to undertake for conservation.

\section{MATERIALS AND METHODS}

\section{$>$ Study Areas}

The study is within the Lake Mainit watershed area in the province of Surigao del Norte and Agusan del Norte. Two sites were chosen, site 1 at Barangay Cantugas, Mainit, Surigao del Norte and site 2 at San Pablo, Jabonga, Agusan del Norte. Each site covered lowland and upland areas.

The type of vegetations observed site 1 lowland were the dipterocarps and patches of premium tree species such as Pterocarpus indicus, Dao (Dracontomelon dao) and Kamagong (Diospyrus philippensis). Some rare wildlife flora and fauna are also found in the area such as Kalau and primate species as indicators of a regenerating tropical rainforest. Coconut trees intercropped with falcata and some agricultural crops were also observed. It has stony substrate and the ground covers are mostly ferns, grasses and wildlings with an elevation ranging from 200 to 500 meters above sea level. While the site 1 upland have patches of abandoned coconut and abaca plantation, dominated by endemic tree species and some notable wildlife such as Rafflesia mixta with an elevation ranging from 519 to 805 meters above sea level, a very steep slope with humus and rocky substrate, ground covers are mostly ferns, mosses, lianas and wildlings.

Site 2 is located in Sitio Dinarawan of Barangay San Pablo, Agusan del Norte. The area is adjacent to the lake with a very steep slope at lower portion and gradually becoming rolling at the ridge with intermittent water 
system and disturbed habitat due to hunting and gathering of forest products by forest occupants. The lowland area is shrubby forest, some portions are planted with falcata, coconut and other agricultural crops such as banana, pineapple and papaya. It has rocky substrate, elevation ranging from 98 to 221 meters above sea level, ground covers are mostly ferns, grasses, vines and wildlings. While the upland area was observed to have vegetation like ferns, Mangium plantation and endemic species of forest trees. The substrates found were humus and sandy substrate and elevation ranging from 421 to 522 meters above sea level. The most notable species is Mancono "the Philippine Iron wood".

\section{Sampling design}

The transect and quadrat method was employed in the study. Two transects were established per area, laid in the lowland and the upland. Nine sampling plots with a dimension of $20 \mathrm{~m} \times 20 \mathrm{~m}$ was laid along the two kilometers transect line with an interval of 250 meters. All floral species (fern, fern allies, grass, herbs, palms, trees and shrubs, vines) found within the sampling plots were recorded, measured, counted and assessed.

Plant species identification, endemicity and conservation status

Plant species were identified with the help of local guides and collection of sample specimen for unidentified plants were done for further identification. Assessment in terms of conservation status and endemicity were based on the International Union for Conservation of Nature and Natural Resources (IUCN) and the Philippine List of Threatened Species DAO 2017-11 otherwise known as the Updated National List of Threatened Philippine Plants and their Categories.

\section{Data Analysis}

The community structure of plants based on species abundance was also analyzed using a series of ecological community structure analysis including cluster analysis (CA) and non-metric multidimensional scaling (nMDS). Prior to the analysis, the abundance data was transformed using square root transformation technique and were subjected to Bray-Curtis similarity coefficient using Plymouth Routine in Multivariate Ecological Research (PRIMER 6) software.

The diversity of plants was computed using the Shannon-Wiener's diversity index (Shannon \& Wiener, 1963), which indicates a quantitative description of plant species in terms of species distribution and evenness with the aid of Paleontological Statistics Software developed by Hammer, et al (2001).

\section{$>$ Adequacy of Sampling Effort}

The species accumulation plot showed increased accumulation rates of plant species with increasing area sampled (Figure 1). This indicated a highly adequate sampling effort as depicted by the saturation and asymptotic curves of species richness estimators (i.e MM, UGE) and actual observed species (Sobs). The results were further supported by the similarity in the mean values of species estimators with observed species (Sobs). The actual observed species had a mean of 169 with standard deviation (Sobs SD) of 13.126 species. This value is the same with two species estimators, Michaelis Menten (MM) and UGE, with a mean value of 169 suggesting highly sufficient plant survey covering the majority of the species in the area. When bootstrapped at 999 permutations, it showed that 13 more species can be recorded if sampling intensity increases. However, the expected number of species to be found if sampling frequency increases may not affect the current sampling effort.

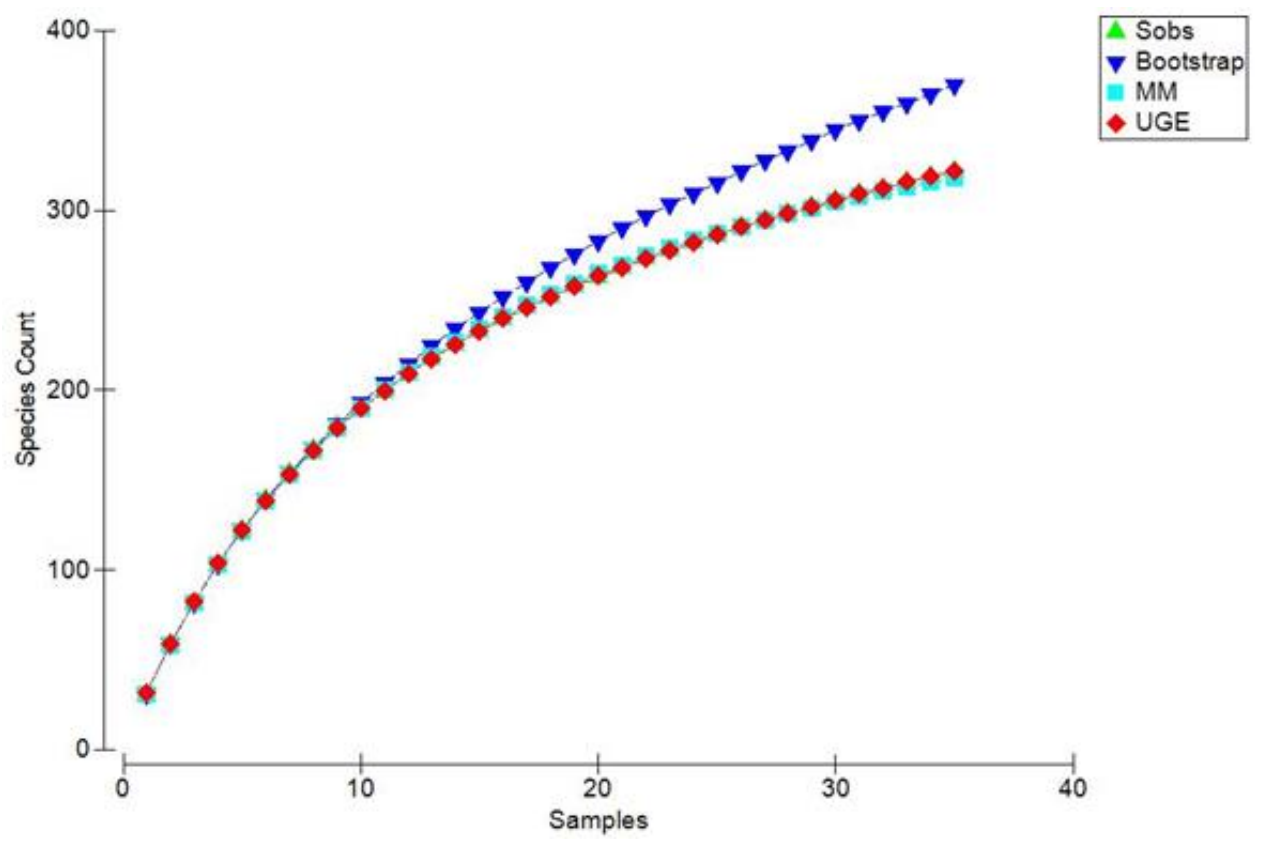

Fig 1:- Species Accumulation Curve of Terrestrial Flora in Jabonga and Cantugas Sampling Sites 


\section{RESULTS AND DISCUSSIONS}

\section{Species Composition}

A total of 321 floral species distributed into 85 families were recorded within two sampling sites. As shown in figure 2, Site 2 (Jabonga) has the highest number of species with 260 observed and distributed in 79 families, while Site 1 (Cantugas) has 158 species distributed into 60 families.

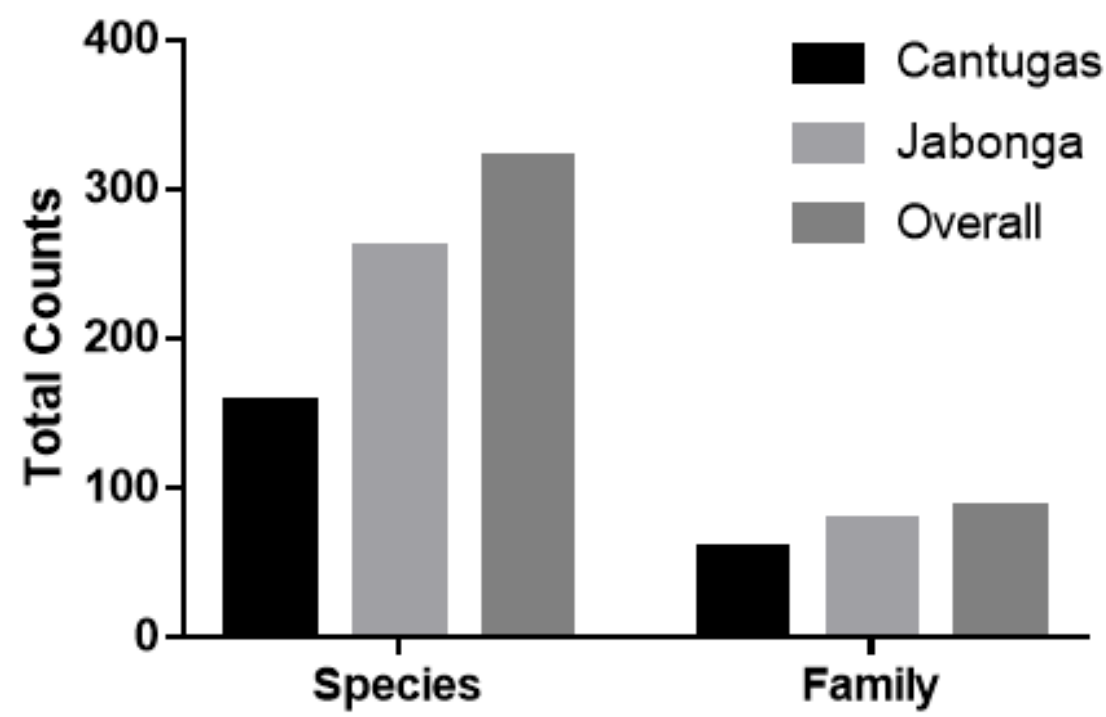

Fig 2:- The abundance of species and families of plants in Lake Mainit Watershed

The taxonomically well-represented families within the two sampling sites were Arecaceae, Fabaceae and Moraceae which registered the highest number of species with 18, 17 and 14 respectively (Table 1). In Jabonga: Arecaceae, Fabaceae, Moraceae were the most dominant families with 17, 13, 13 species respectively, while in Cantugas: Fabaceae, Arecaceae, Moraceae were the most dominant families with 9, 8, 8 species respectively. A similar study conducted by Demetillo et al (2015), Fabaceae, Moraceae, Myrtaceae, and Rubiaceae were amongst the most dominant families in the watershed area of Lake Mainit.

\begin{tabular}{|c|c|c|c|}
\hline Rank & Jabonga & Cantugas & Overall \\
\hline 1 & Arecaceae (17) & Fabaceae (9) & Fabaceae (17) \\
\hline 2 & Fabaceae (13) & Arecaceae (8) & Moraceae (14) \\
\hline 3 & Moraceae (13) & Moraceae (8) & Araceae (10) \\
\hline 4 & Euphorbiaceae (10) & Mraceae (7) & Dipterocarpaceae (9) \\
\hline 5 & Araceae (7) & Euphorbiaceae (5) & Myrtaceae (8) \\
\hline 6 & Dipterocarpaceae (7) & Poaceae (5) & Mabiaceae (8) \\
\hline 7 & Malvaceae (7) & Dipterocarpaceae (4) & Musaceae (7) \\
\hline 9 & Rubiaceae (7) & Rubiaceae (4) \\
\hline 10 & Musaceae (6) & Asteraceae (3) & Myrtaceae (6) \\
\hline
\end{tabular}

Table 1:- The proportion of plant families representing the sampling sites. Shown are the top 10 most represented families and the number of species per family in parenthesis

Family Arecaceae is characterized by having various growth forms and can grow best in moist and shady areas and usually among the most cultivated plant families. Species of these families are often used as materials for constructions, food, handicrafts, rituals and therapeutics (Bates, 1988). Fabaceae family can thrive well in ultramafic areas with low amounts of essential nutrients because of its ability to fix nitrogen in the atmosphere with the help of associated Rhizobacteria in their roots. The importance of Fabaceae family for health and human alimentation is highlighted, although they also provide wood resources and dyes, resins, insecticides, fibers, fodder (Isely, 1982). The family Moraceae commonly known as mulberry or fig family has many representative species with cosmopolitan distribution and widely spread in different habitats of the tropical region.

The plant species recorded in the area were characterized into seven (7) plant habit groupings including herbs, grass, vine, palm, ferns, fern allies, and trees and shrubs (Table 2). Among the plant habits, Trees and Shrubs accounts the highest number of species with $58.255 \%$, 
ISSN No:-2456-2165

followed by Herb (15.576\%), Fern (7.165\%), Vine $(6.542 \%)$, Palm $(5.607 \%)$, Grass $(2.804 \%)$ and Fern Allies $(0.935 \%)$. The abundance of trees and shrubs indicates that there is less to intermediate human-induced anthropogenic disturbance within two sites especially in the upland where the advance secondary forest was still present. It could also support the growth of herbs and vines in the forest floor. The abundance of palms and ferns indicates that the area was disturbed especially in the lowland where anthropogenic activities are very common such kaingin and establishment of coconut plantation which facilitates the growth of several fern species.

\begin{tabular}{|c|c|c|c|}
\hline Plant Group & Jabonga & Cantugas & Overall \\
\hline Fern & 18 & 15 & 23 \\
\hline Fern Allies & 3 & 3 & 3 \\
\hline Grass & 7 & 5 & 50 \\
\hline Herb & 41 & 28 & 18 \\
\hline Palm & 16 & 8 & 187 \\
\hline Trees and Shrubs & 157 & 90 & 21 \\
\hline Vine & 18 & 9 & $\mathbf{3 2 1}$ \\
\hline Total & $\mathbf{2 6 0}$ & $\mathbf{1 5 8}$ & \\
\hline
\end{tabular}

Table 2:- The seven plant habit groupings in the sampling sites. Values are number of species per plant group.

\section{Species Diversity}

The floristic data collected in the field were subjected to diversity profiles and biodiversity analyses (Table 3; Figure 3). The diversity measurements were calculated including species richness, evenness, dominance, abundance, and Shannon diversity. When the resulting species abundance was pooled in each site, it showed that there is a moderate diversity in Cantugas lowland, low diversity in Cantugas upland and high diversity in Jabonga lowland and upland based on Fernando Biodiversity Scale (1998). The Jabonga lowland had the highest species richness, abundance, and Shannon Diversity. The highest dominance was observed in Cantugas upland. In contrast, Cantugas upland gave the lowest values of species evenness and Shannon Diversity. Evenness was almost the same in Cantugas lowland, Jabonga lowland and upland.
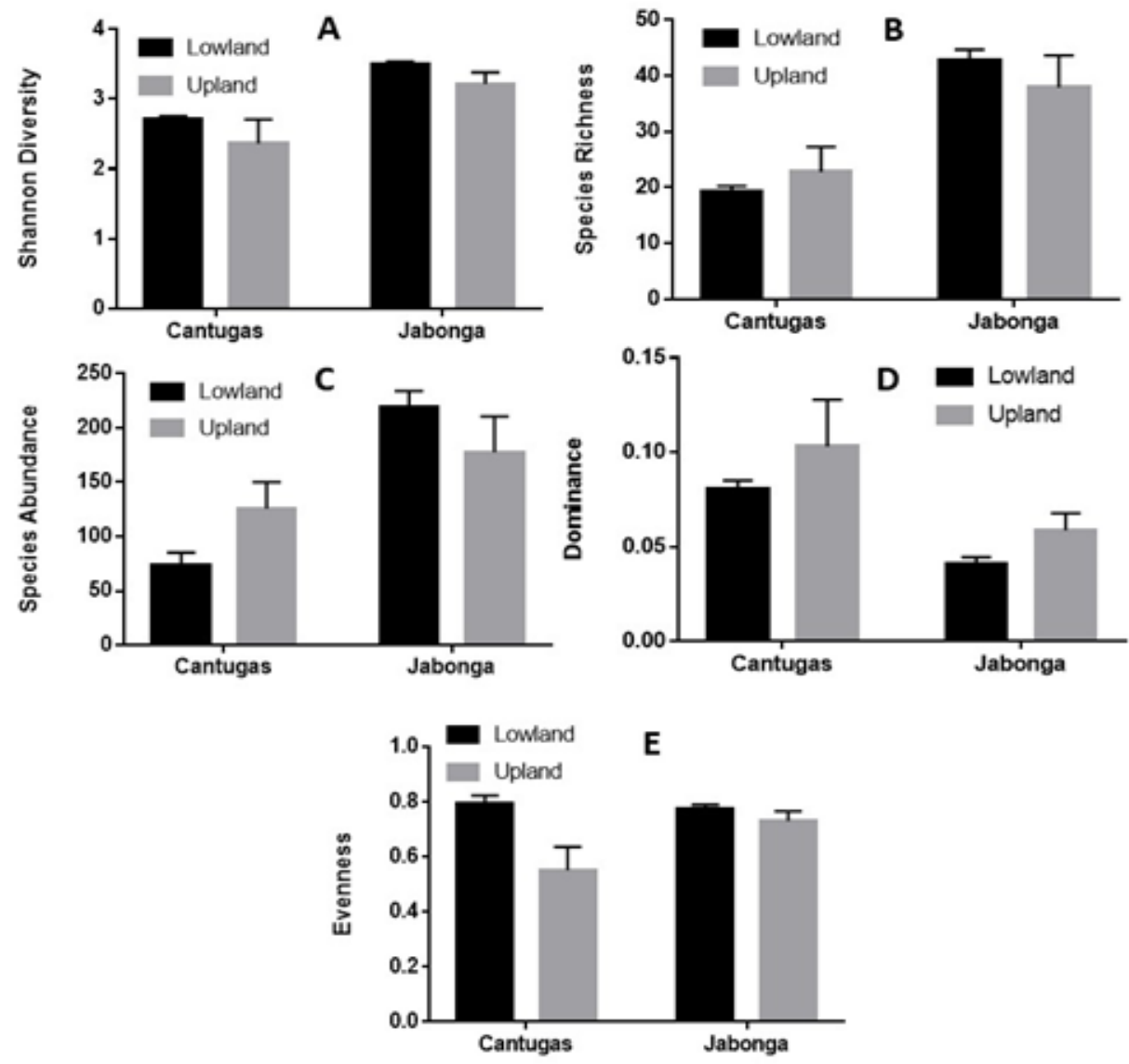

Fig 3:- The comparison of biodiversity indices in the sampling locations and elevation including a) Shannon diversity, b) Species

Richness, c) Abundance d) Dominance and e) Evenness. Shown are mean \pm SE of diversity indices. 
ISSN No:-2456-2165

The plant diversity measurements were also analyzed and compared between sampling areas and elevation using Two-way ANOVA (Table 3). The analysis detected a significantly higher difference in species richness ( $\mathrm{F}=26$ ), species abundance $(\mathrm{F}=18.9)$, Shannon diversity $(\mathrm{F}=17.5)$ and dominance $(\mathrm{F}=9.6)$ between sampling areas. On the other hand, there is a significant difference in species evenness between elevations $(\mathrm{F}=8.65)$ and between elevation*sampling areas $(\mathrm{F}=4.3)$.

\begin{tabular}{|c|c|c|c|c|c|}
\hline $\begin{array}{c}\text { Test Factor and Source of } \\
\text { Variation }\end{array}$ & $\begin{array}{c}\text { Shannon } \\
\text { diversity }\end{array}$ & $\begin{array}{c}\text { Species } \\
\text { Richness }\end{array}$ & $\begin{array}{c}\text { Species } \\
\text { Abundance }\end{array}$ & $\begin{array}{c}\text { Dominanc } \\
\text { e }\end{array}$ & $\begin{array}{c}\text { Evennes } \\
\text { s }\end{array}$ \\
\hline Sampling Areas & $17.5^{* * *}$ & $26^{* * *}$ & $18.9^{* * *}$ & $9.6^{* *}$ & 2.6 \\
\hline Elevation & 2.5 & 0.03 & 0.06 & 2.1 & $8.65^{*}$ \\
\hline Elevation*Sampling areas & 0.03 & $\mathbf{1 . 2 2}$ & $4.25^{*}$ & 0.03 & $4.3^{*}$ \\
\hline
\end{tabular}

Table 3:- Two-way ANOVA results (F-ratios and significance levels) for the comparison of biodiversity measurements between sampling areas and elevations. Significance levels: "*" $\mathrm{p}<0.05, " * * " \mathrm{p}<0.01$, and "***" $\mathrm{p}<0.001)$

\section{Community Structure and Ordination}

The community structure of plants based on species abundance was analyzed using a series of ecological community structure analysis including cluster analysis and non-metric multidimensional scaling (NMDS). Prior to the analysis, the abundance data was transformed using a square root transformation technique and was subjected to Bray-Curtis similarity coefficient. Then, the similarity matrix was used to analyze the community structure of plants using the previously mentioned analyses.

The cluster analyses through hierarchical agglomerative clustering method and non-metric multidimensional scaling (NMDS) were used to find natural grouping patterns of sites with similar species assemblages (Figure 5). Based on the dendrogram, there were three distinct groupings of plots sampled from the two sampling sites at $25 \%$ similarity. The biggest group form was comprised of all sampling plots from Jabonga lowland. On the other hand, all sampling plots from Cantugas lowland discriminate independently into two separate grouping patterns in the tree diagram. This suggested a unique plant species composition in the sites.

With NMDS, the relative position of sampling sites in the two-dimensional graph also explains the distribution of plant communities in the area. The analysis is non-metric therefore the plot has no scale. Similar to cluster analyses, there were four groups created at $25 \%$ similarity; the Jabonga lowland was pooled into one group with $20 \%$ similarity index, whereas Cantugas lowland was divided into two plant groups with $25 \%$ similarity index which suggest a lower species similarity or a unique plant grouping.

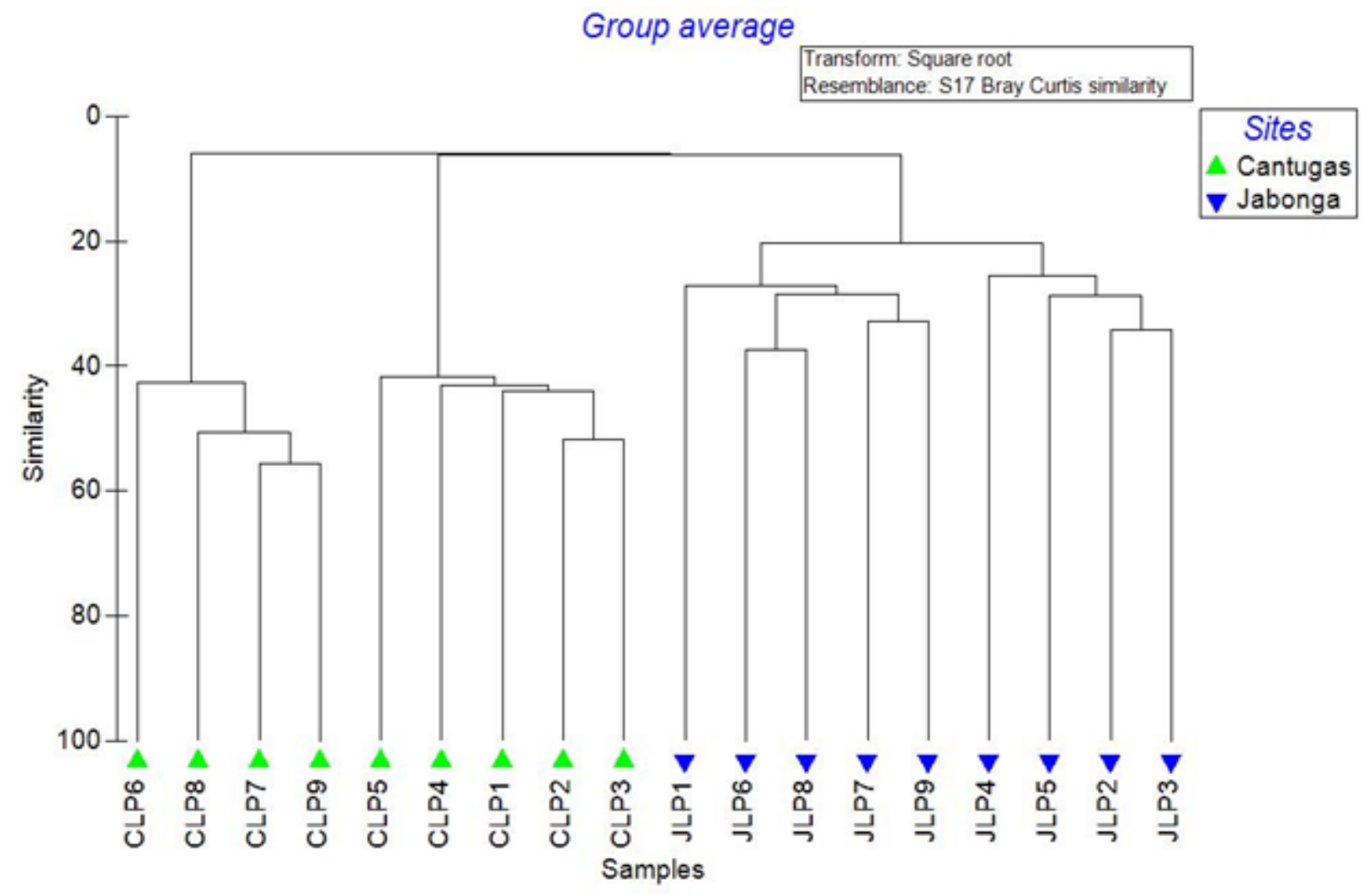

Fig 4 


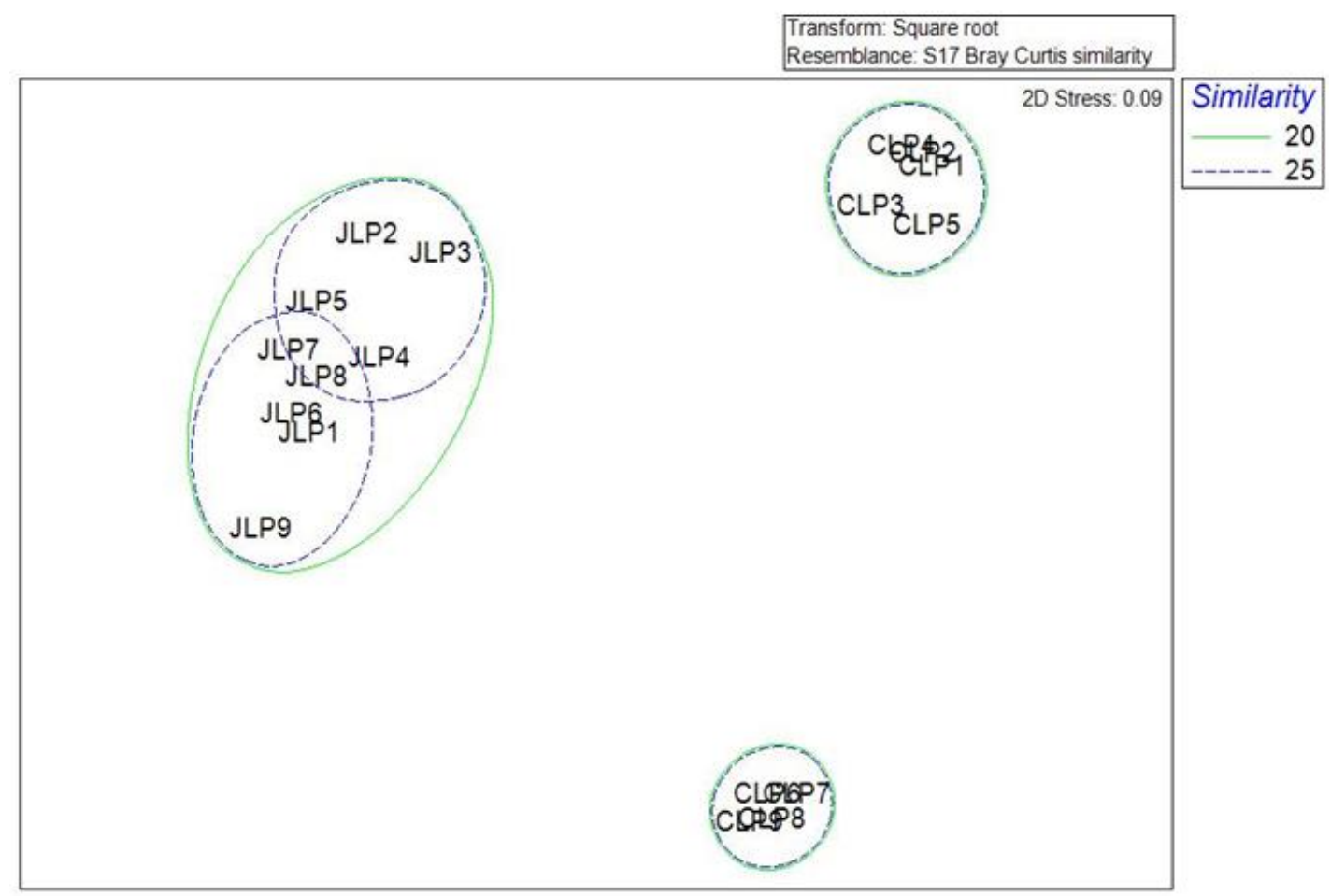

Fig 5:- Dendrogram of Cluster analysis and Non-metric Multidimensional scaling (NMDS) plot showing the Bray-curtis similarities of the terrestrial flora in lowland of Jabonga and Cantugas sampling sites

The dendrogram of Cantugas and Jabonga uplands on Cluster analysis and Non-metric Multidimensional scaling (NMDS) as shown in Fig. 6 suggest five plant groupings. The biggest group was comprised of six sampling plots from Jabonga upland which indicated the co-occurrence of floral species in these sampling plots. On the other hand, the Cantugas lowland discriminates independently into two separate grouping patterns in the tree diagram, in which plot 1 to 4 has a different plant composition from plot 6 to 8 . This suggested a unique plant species composition in this site.
With $20 \%$ similarity in NMDS; the Jabonga upland formed the biggest group which indicates higher plant species similarity among the area, whereas Cantugas upland was divided into two plant groupings which suggest a lower species similarity or a unique plant grouping. Although, the overlapping of confidence ellipses to some degree may indicate overlapping of species composition probably due to the proximity of locations allowing exchanges of plant species within these areas.

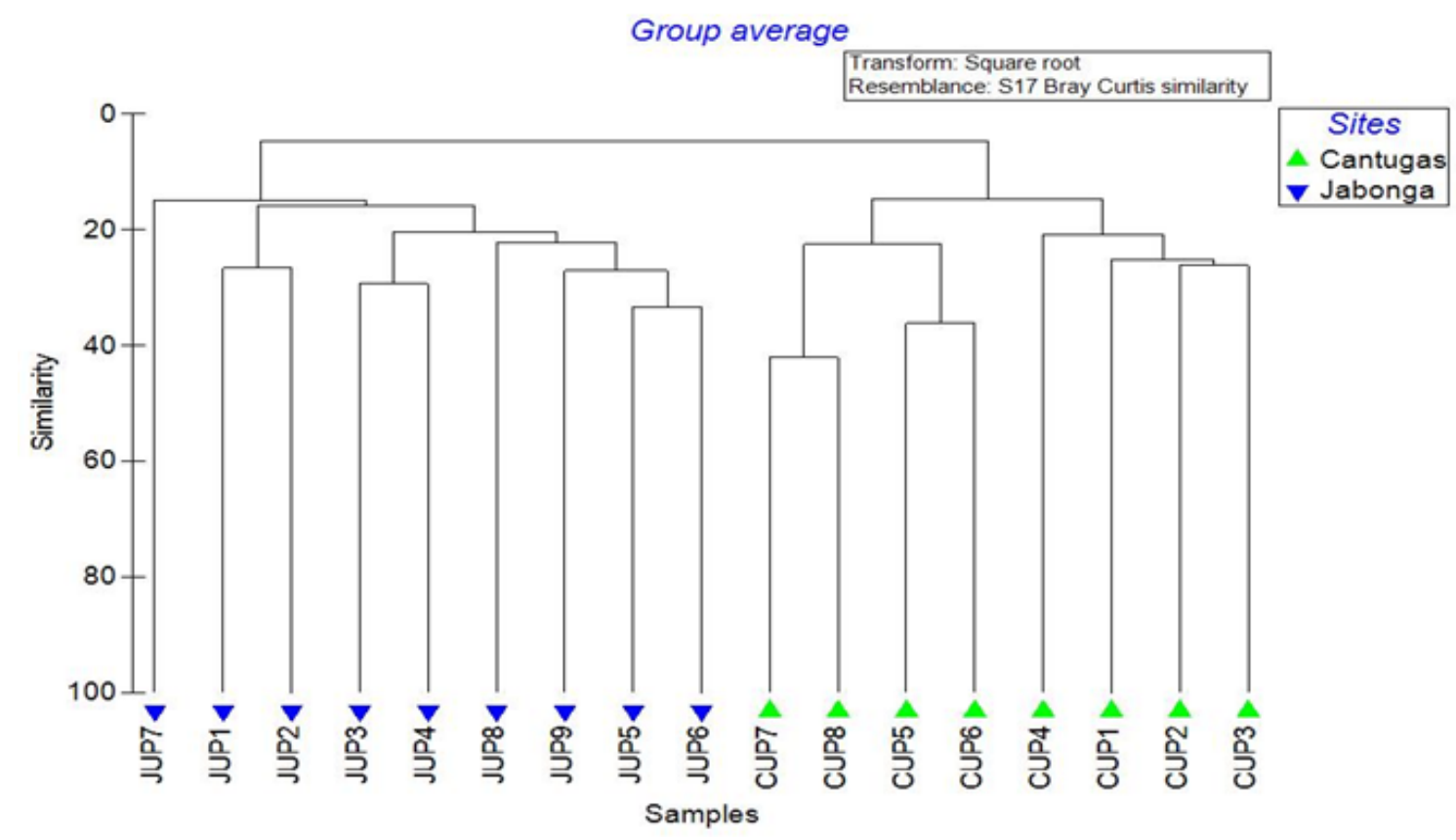


ISSN No:-2456-2165

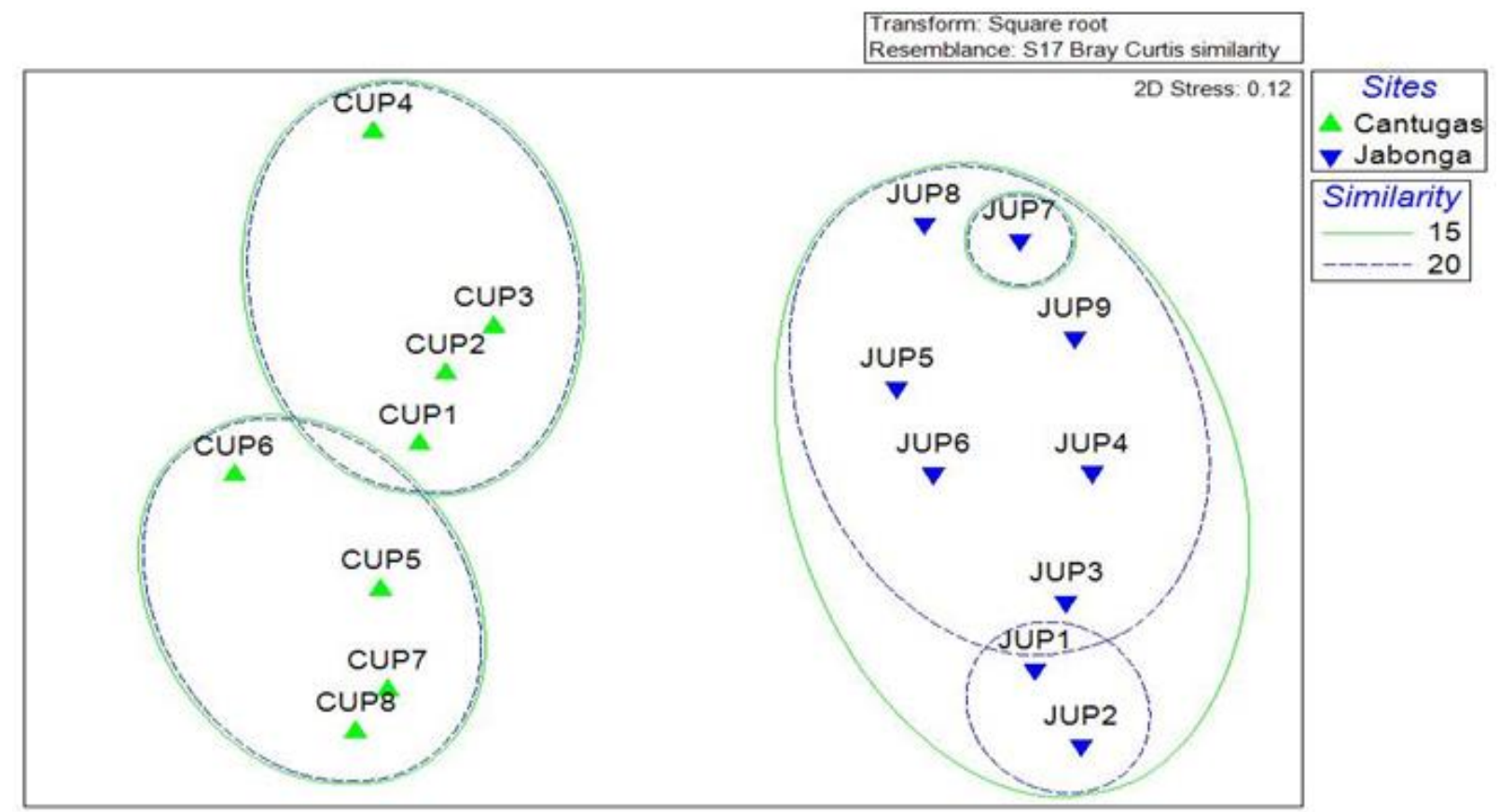

Fig 6:- Dendrogram of Cluster analysis (a) and Non-metric Multidimensional scaling (NMDS) plot showing the Bray-curtis similarities of the terrestrial flora in upland of Jabonga and Cantugas sampling sites

When the species from both sampling sites were pooled, the dendrogram for cluster analysis shows a unique composition of plant species between two sampling sites and between lowland and upland. Though it suggests a lower species similarity between sampling sites, the plant species of both sampling sites lowland and upland has a high species similarity index.

With $15 \%$ similarity and a stress value of 0.21 in NMDS; the Jabonga upland and lowland formed the biggest group which indicates higher plant species similarity among the sites, whereas Cantugas upland was divided into two plant groupings which suggest a lower species similarity or a unique plant grouping, while Cantugas lowland formed a single group. Although, the overlapping of confidence ellipses to some degree may indicate overlapping of species composition probably due to the proximity of locations allowing exchanges of plant species within these areas.

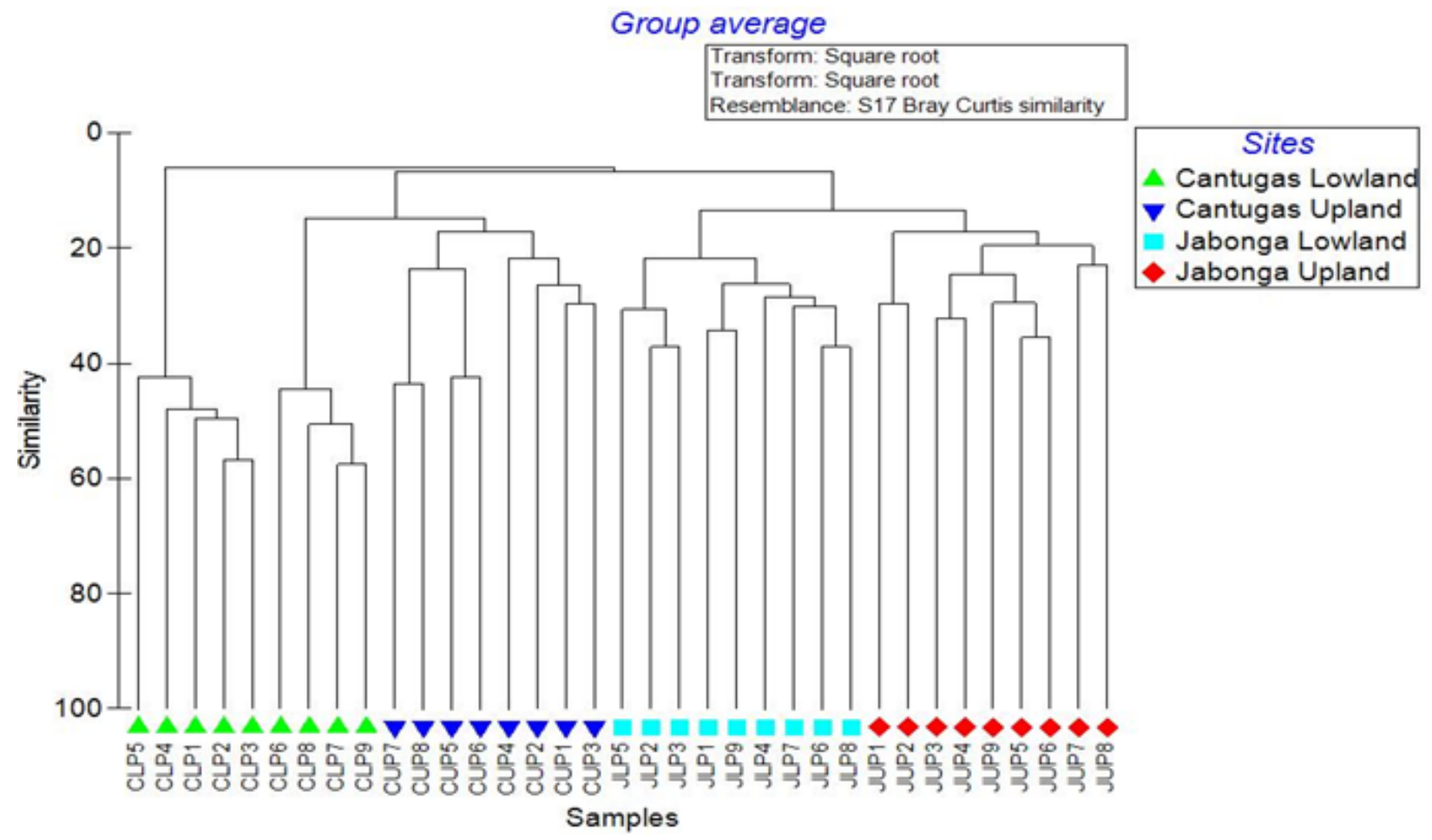




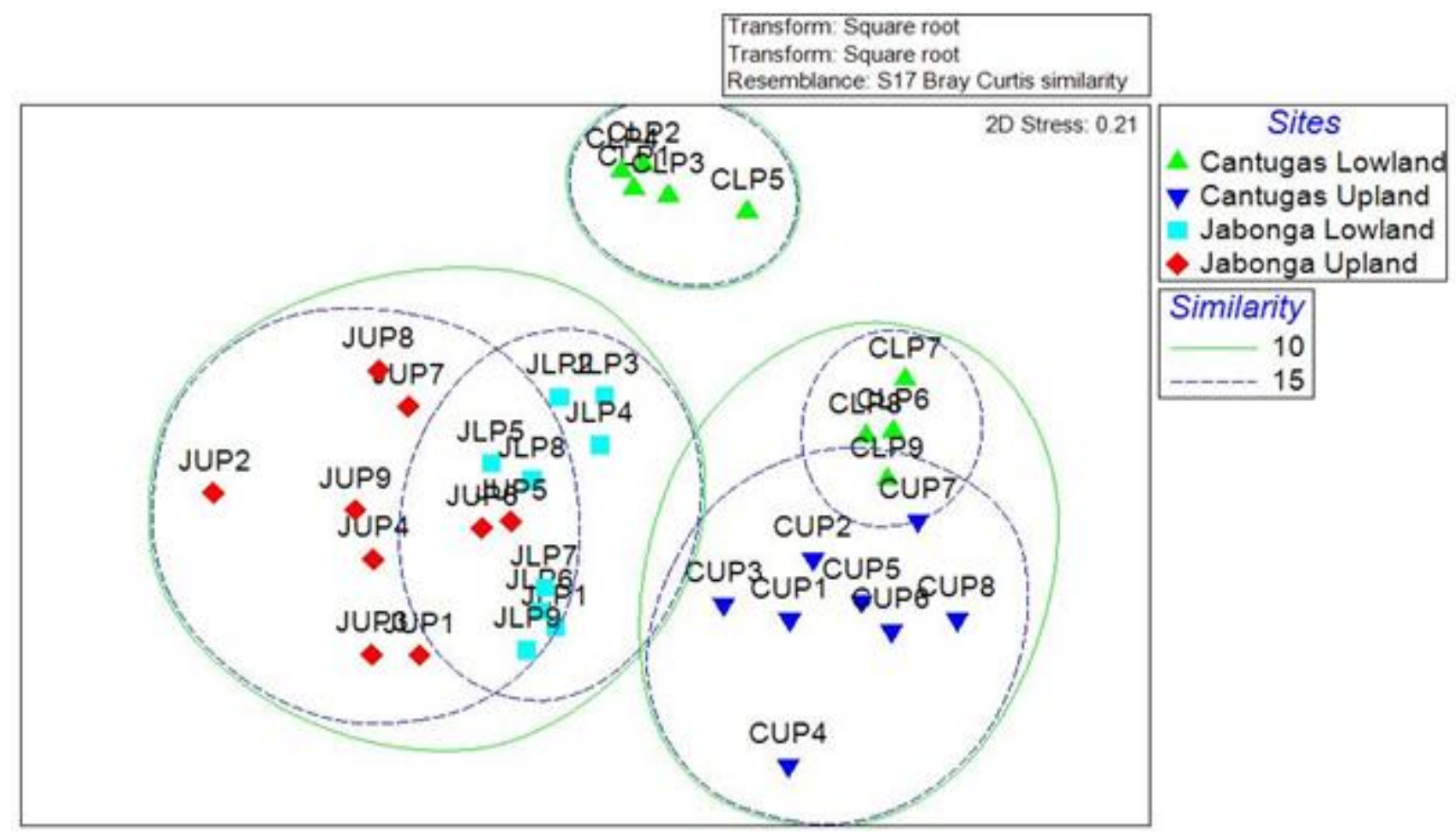

Fig 7:- Dendrogram of Cluster analysis (a) and Non-metric Multidimensional scaling (NMDS) plot showing the Bray-curtis similarities of the terrestrial flora pooled across all sampling sites and elevation

\section{Plant Conservation Status and Endemicity}

Of the all plant species encountered, 9 species were critically endangered; 1 endangered; and 14 species were vulnerable based on the International Union for Conservation of Nature and Natural Resources, while there were 2 critically endangered, 2 endangered, 10 vulnerable and 3 other threatened species found within the two sampling sites as listed in DAO 2017-11 (Appendix 1). The presence of this threatened species urges a given sufficient protection measures in order to ensure their continued existence in the wild.

Of the total 321 species encountered within the two sampling sites, 20 species were classified Philippine endemic, 49 endemic species, 26 native species, and 29 introduced species. The Philippine endemic species were species which could only be seen in the country and most of these species were threatened and endangered such as Hopea acuminata, Shorea contorta, Shorea negrosensis, Shorea polysperma, Myristica philippinensis and Mitrepora lanotan. Some of the introduced species which were also classified as an invasive species such as Chromolaena odorata, Mimosa pigra and Sacharrum spontaneum were also present in the watershed area of Lake Mainit.

\section{CONCLUSION}

The study recorded a total of 321 plant species, $58.255 \%$ of this species were trees and shrubs, 20 species were Philippine endemic, 24 species were classified threatened by the IUCN and 17 threatened species based on the DAO 2017-11. The area is considered moderately high in terms of diversity status with high endemicity status which is noteworthy for conservation and protection. Most of these threatened species were distributed in both sampling sites but diminishing in numbers due to natural and several anthropogenic activities thus these areas worth conserving and preserving for future use. The result of this study is very useful to develop the template for the local ordinance to support local endemics.

\section{REFERENCES}

[1]. Bates, D. M. (1988). Utilization pools: a framework for comparing and evaluating the economic importance of palms. Advances in Economic Botany, vol. 6, pp. 56-64;

[2]. DAO 2017-11. (2017). Updated National List of Threatened Philippine Plants and Their Categories;

[3]. Demetillo, M. T., Lador, R. P., and Seronay, R. A. (2016). Floral Assessment in Lake Mainit Watershed, Caraga, Mindanao, Philippines. Annals of Studies in Science and Humanities;

[4]. Gracia, D. M. (1981). Report on the hydrobiological survey and inventory of aquatic resources of Lake Mainit, Mindanao Island. Terminal report. Manila, BFAR Fish Propagation Division;

[5]. Fernando, E.E. (1998). Forest Formations and Econ. of the Phils: Handout in FBE 21 College of Foresty \& Natural Science, UPLB;

[6]. Hall, C.A.S., Hall, M.H, P., 1993. The Efficiency of Land and Energy use in Tropical Economics Environment. 46, 1-30;

[7]. Hammer O, Harper DAT \& Ryan P.D. (2001). PAST: Paleontological Statistic Software Package for Education and Data Analysis. Paleontologia electronica 4 (1); 
[8]. Isely, D. (1982). Leguminosae and Homo sapiens I. Economic Botany, vol. 36, no. 1, pp. 46-70;

[9]. IUCN. (2017). IUCN Red List of Threatened Species. Version 2010.1. Electronic Database accessible at www.iucnredlist.org.;

[10]. Lake Mainit Development Alliance - Environmental Management Plan, 2014;
[11]. Mahtab, F.V. \& Harim, Z. (1992). Population and Agricultural Land Use; Towards a Sustainable Food Production Sytem in Bangladesh. Ambio 21, 50-55;

[12]. Shannon, C.E. \& Wiener, W. (1963). The Mathematical Theory of communication University of Illinois Press. Urbana, Illinois.

\section{APPENDIX 1}

List of Floral Species Found Within the Two Sampling Sites with Conservation Status, Endemicity and Plant Habit

\begin{tabular}{|c|c|c|c|c|c|}
\hline Family Name & Scientific Name & Common Name & Plant Habit & $\begin{array}{c}\text { Conservation } \\
\text { Status }\end{array}$ & Endemicity \\
\hline Amaranthaceae & Amaranthus sp. & & Herb & & \\
\hline Anacardiaceae & Anacardia sp. & Manga-manga & $\begin{array}{l}\text { Tree \& } \\
\text { Shrub }\end{array}$ & & \\
\hline Annonaceae & Annonaceae & Urayo & $\begin{array}{l}\text { Tree \& } \\
\text { Shrub }\end{array}$ & & \\
\hline Annonaceae & $\begin{array}{c}\text { Cananga odorata (Lam.) Hook.f. \& } \\
\text { Thomson }\end{array}$ & Alangilan & $\begin{array}{l}\text { Tree \& } \\
\text { Shrub }\end{array}$ & & Native \\
\hline Annonaceae & Mitrephora lanotan (Blanco) Merr. & Lanutan & $\begin{array}{l}\text { Tree \& } \\
\text { Shrub }\end{array}$ & VU $^{1}$ OTS $^{2}$ & $\begin{array}{c}\text { Phil } \\
\text { Endemic }\end{array}$ \\
\hline Apocynaceae & Alstonia scholaris (L.) R.Br. & Dita & $\begin{array}{l}\text { Tree \& } \\
\text { Shrub }\end{array}$ & & Native \\
\hline Apocynaceae & Wrightia pubescens R.Br., 1811 & Laniti & $\begin{array}{l}\text { Tree \& } \\
\text { Shrub }\end{array}$ & $\mathrm{LC}^{1}$ & Endemic \\
\hline Apocynaceae & Dischidia sp. & & Vine & & \\
\hline Apocynaceae & Hoya sp. & & Vine & & \\
\hline Araceae & Aglaonema sp. & & Herb & & \\
\hline Araceae & Alocasia macrorrhizos (L.) G.Don & & Herb & & Endemic \\
\hline Araceae & Alocasia zebrina Schott ex Van Houtte & & Herb & & Endemic \\
\hline Araceae & Araceae & Panangkilon & Herb & & \\
\hline Araceae & Colocasia esculenta (L.) Schott & Taro & Herb & & Native \\
\hline Araceae & Epipremnum pinnatum (L.) Engl. & & Vine & & Endemic \\
\hline Araceae & Homalomena philippinensis & Payaw & Herb & & $\begin{array}{c}\text { Phil } \\
\text { Endemic }\end{array}$ \\
\hline Araceae & Philodendron sp. & & Vine & & \\
\hline Araceae & Pothos sp. & Lukmoy & Vine & & \\
\hline Araceae & Rhapidopora sp. & & Herb & & \\
\hline Araceae & $\begin{array}{l}\text { Selaginella delicatula (Desv. ex Poir.) } \\
\text { Alston }\end{array}$ & Butitay & Fern Allies & & \\
\hline Araliaceae & Arthrophyllum borneense Merr. & Bingliw & $\begin{array}{l}\text { Tree \& } \\
\text { Shrub }\end{array}$ & & \\
\hline Araliaceae & Osmoxylon diversifolium & & $\begin{array}{l}\text { Tree \& } \\
\text { Shrub }\end{array}$ & & \\
\hline Araliaceae & Polyscias nodosa Blume & Malapapaya & $\begin{array}{l}\text { Tree \& } \\
\text { Shrub }\end{array}$ & & \\
\hline Arecaceae & Areca catechu L. & Bunga & Palm & & Endemic \\
\hline Arecaceae & Arenga pinnata (Wurmb) Merr. & Kaong & Palm & & \\
\hline
\end{tabular}


ISSN No:-2456-2165

\begin{tabular}{|c|c|c|c|c|c|}
\hline Family Name & Scientific Name & Common Name & $\begin{array}{l}\text { Plant } \\
\text { Habit }\end{array}$ & $\begin{array}{c}\text { Conservation } \\
\text { Status } \\
\end{array}$ & Endemicity \\
\hline Arecaceae & Baris palm & Baris palm & Palm & & \\
\hline Arecaceae & Calamus microcarpus & Rattan / Piyay & Palm & & \\
\hline Arecaceae & $\begin{array}{l}\text { Calamus microcarpus var. } \\
\text { microcarpus }\end{array}$ & Paag daga & Palm & & \\
\hline Arecaceae & Calamus mitis & & Palm & & \\
\hline Arecaceae & Calamus sp. 1 & Bal-esan & Palm & & \\
\hline Arecaceae & Calamus sp. 2 & Atibangalan & Palm & & \\
\hline Arecaceae & Caryota cumingi & Pugahan & Palm & $\mathrm{LC}^{1}$ & Endemic \\
\hline Arecaceae & Cocos nucifera $\mathrm{L}$. & Niyog & $\begin{array}{l}\text { Tree \& } \\
\text { Shrub }\end{array}$ & & \\
\hline Arecaceae & Orania palindan Blanco & Banga & Palm & $\mathrm{VU}^{2}$ & Endemic \\
\hline Arecaceae & Pinanga insignis Becc. & Rattan / Sarawag & Palm & & Endemic \\
\hline Arecaceae & Pinanga maculata & & Palm & & Endemic \\
\hline Arecaceae & Pinangga sp. & Biga palm & Palm & & \\
\hline Arecaceae & Rattan / Kurambuto & $\begin{array}{c}\text { Rattan / } \\
\text { Kurambuto }\end{array}$ & Palm & & \\
\hline Arecaceae & Rattan / Tublangag & $\begin{array}{c}\text { Rattan / } \\
\text { Tublangag }\end{array}$ & Palm & & \\
\hline Fabaceae & Securinega flexuosa Muell.-Arg. & Anislag & $\begin{array}{l}\text { Tree \& } \\
\text { Shrub }\end{array}$ & $\mathrm{VU}^{1}$ & Phil Endemic \\
\hline Arecaceae & Tamsi palm & Tamsi palm & Palm & & \\
\hline Asparagaceae & Dracaena sp. & & Herb & & \\
\hline Asphodelaceae & Dianella sp. & & Herb & & \\
\hline Aspleniaceae & Asplenium nidus $\mathrm{L}$. & & Fern & & Native \\
\hline Aspleniaceae & Asplenium polyodon $\mathrm{G}$. Forst & & Fern & & Introduced \\
\hline Asteraceae & Blumea sp. & Sambong & Herb & & \\
\hline Asteraceae & $\begin{array}{c}\text { Chromolaena odorata(L.) R.M.King \& } \\
\text { H.Rob. }\end{array}$ & Hagonoy & Herb & & Introduced \\
\hline Asteraceae & Elephantopus tomentosusL. & Elepante & Herb & & Introduced \\
\hline Asteraceae & Mikania cordata Kunth & Mote-mote & Vine & & \\
\hline Athyriaceae & Diplazium esculentum (Retz.) Sw. & Pako & Fern & $\mathrm{LC}^{1}$ & Endemic \\
\hline Begoniaceae & Begonia bolsteri Merr. & & Herb & & \\
\hline
\end{tabular}

Table 5

\begin{tabular}{|c|c|c|c|c|c|}
\hline Family Name & Scientific Name & $\begin{array}{c}\text { Common } \\
\text { Name }\end{array}$ & Plant Habit & $\begin{array}{c}\text { Conservation } \\
\text { Status }\end{array}$ & $\begin{array}{c}\text { Endemicit } \\
\text { y }\end{array}$ \\
\hline Begoniaceae & Begonia pseudolateralis Warb. & & Herb & & \\
\hline Begoniaceae & Begonia sp. & & Herb & & \\
\hline Begoniaceae & Begonia sp. 1 & Herb & & \\
\hline Bignoniaceae & Radermachera pinnata Blanco & Banay-banay & $\begin{array}{c}\text { Tree \& } \\
\text { Shrub }\end{array}$ & LC $^{1}$ & \\
\hline Bignoniaceae & Tecoma stans (L.) Juss. Ex Kunth & Kampanilya & $\begin{array}{c}\text { Tree \& } \\
\text { Shrub }\end{array}$ & & \\
\hline Bignoniaceae & Schismatoglottis sp. & Pusaw & Herb & & Introduced \\
\hline Bromeliaceae & Ananas comosus (L) Merr. & Pinya & Herb & & native \\
\hline Burseraceae & Canarium ovatum Engl. & Pili & $\begin{array}{c}\text { Tree \& } \\
\text { Shrub }\end{array}$ & $\mathrm{VU}^{1}$ & \\
\hline Burseraceae & Canarium $s p .1$ & Pagsahangin & $\begin{array}{c}\text { Tree \& } \\
\text { Shrub }\end{array}$ & $\mathrm{LC}^{1}$ & \\
\hline
\end{tabular}


ISSN No:-2456-2165

\begin{tabular}{|c|c|c|c|c|c|}
\hline Burseraceae & Canarium sp. 2 & Sagasa & $\begin{array}{l}\text { Tree \& } \\
\text { Shrub }\end{array}$ & & \\
\hline Calophylaceae & $\begin{array}{c}\text { Calophyllum blancoi Planch. \& } \\
\text { Triana } \\
\end{array}$ & Bitanghol & $\begin{array}{l}\text { Tree \& } \\
\text { Shrub }\end{array}$ & & Endemic \\
\hline Calophylaceae & Calophylum inophyllum $\mathrm{L}$. & Bitaog & $\begin{array}{l}\text { Tree \& } \\
\text { Shrub }\end{array}$ & $\mathrm{LC}^{1}$ & Native \\
\hline Cannabaceae & Trema orientalis (L.) Blume & Hanagdong & $\begin{array}{l}\text { Tree \& } \\
\text { Shrub }\end{array}$ & $\mathrm{LC}^{1}$ & Endemic \\
\hline Caricaceae & Carica papaya $\mathrm{L}$. & Papaya & Herb & & Introduced \\
\hline Clethraceae & Clethra canescens Reinw. Ex Blume & Banilag & $\begin{array}{l}\text { Tree \& } \\
\text { Shrub }\end{array}$ & & \\
\hline Clusiaceae & Garcinia ituman Merr. & Ituman & $\begin{array}{l}\text { Tree \& } \\
\text { Shrub } \\
\end{array}$ & & \\
\hline Clusiaceae & Garcinia 1492orella (Gaertn.) Desr. & Batuan & $\begin{array}{l}\text { Tree \& } \\
\text { Shrub }\end{array}$ & & Endemic \\
\hline Clusiaceae & Garcinia rubra Merr. & Kandiiis & $\begin{array}{l}\text { Tree \& } \\
\text { Shrub }\end{array}$ & & \\
\hline Combretaceae & Terminalia nitens Presl. & Magtalisay & $\begin{array}{l}\text { Tree \& } \\
\text { Shrub }\end{array}$ & $\mathrm{VU}^{1}$ & Endemic \\
\hline Commelinaceae & Amischotolype sp. & & Herb & & \\
\hline Commelinaceae & Commelina benghalensis $\mathrm{L}$. & & Herb & & Endemic \\
\hline Costaceae & $\begin{array}{c}\text { Cheilocostus speciosus (J.Konig) } \\
\text { C.Specht }\end{array}$ & Tambabasi & Herb & & Native \\
\hline Cyatheaceae & Cyathea contaminans & Anotong & Fern & $\mathrm{LC}^{1} \mathrm{E}^{2}$ & Endemic \\
\hline Datiscaceae & Octomeles sumatrana Miq. & Binuang & $\begin{array}{l}\text { Tree \& } \\
\text { Shrub }\end{array}$ & & Endemic \\
\hline Dennstaedtiaceae & Pteridium aquilinum (L.) Kuhn & Bracken fern & Fern & $\mathrm{LC}^{1}$ & Introduced \\
\hline
\end{tabular}

\begin{tabular}{|c|c|c|c|c|c|}
\hline Family Name & Scientific Name & $\begin{array}{c}\text { Common } \\
\text { Name }\end{array}$ & Plant Habit & $\begin{array}{c}\text { Conservation } \\
\text { Status }\end{array}$ & Endemicity \\
\hline Dilleniaceae & Dillenia philippinensis Rolfe & katmon & Herb & $\mathrm{VU}^{1}$ & $\begin{array}{c}\text { Phil } \\
\text { Endemic }\end{array}$ \\
\hline Dioscoreaceae & Dioscorea hispida Dennst & Baay/Puyot & Vine & & \\
\hline Dioscoreaceae & Dioscorea sp. 1 & Buyo-buyo & Vine & & \\
\hline Dioscoreaceae & Dioscorea sp. 2 & $\begin{array}{c}\text { Liana / } \\
\text { Panamog }\end{array}$ & Vine & & \\
\hline Dioscoreaceae & Tacca 1492hore a Blume & & Herb & & Endemic \\
\hline Dipterocarpaceae & Dipterocarpaceae & Halong-halong & $\begin{array}{l}\text { Tree \& } \\
\text { Shrub }\end{array}$ & & \\
\hline Dipterocarpaceae & Dipterocarpaceae & Tupsan & $\begin{array}{l}\text { Tree \& } \\
\text { Shrub }\end{array}$ & & \\
\hline Dipterocarpaceae & Dipterocarpus grandiflorus Blanco & Apitong & $\begin{array}{l}\text { Tree \& } \\
\text { Shrub } \\
\end{array}$ & $\mathrm{CE}^{1} \mathrm{VU}^{2}$ & Endemic \\
\hline Dipterocarpaceae & Dipterocarpus mayapis & Mayapis & $\begin{array}{l}\text { Tree \& } \\
\text { Shrub }\end{array}$ & $\mathrm{CE}^{1}$ & Endemic \\
\hline Dipterocarpaceae & Dipterocarpacea & Maglilipot & $\begin{array}{l}\text { Tree \& } \\
\text { Shrub }\end{array}$ & & \\
\hline Dipterocarpaceae & Hopea 1492hore asp Merr. & Manggachapui & $\begin{array}{l}\text { Tree \& } \\
\text { Shrub }\end{array}$ & $\mathrm{CE}^{1}$ & $\begin{array}{c}\text { Phil } \\
\text { Endemic }\end{array}$ \\
\hline Dipterocarpaceae & 1492hore as. & Balit & $\begin{array}{l}\text { Tree \& } \\
\text { Shrub }\end{array}$ & & \\
\hline Dipterocarpaceae & $\begin{array}{c}\text { Parashorea malaanonan (Blanco) } \\
\text { Merr. }\end{array}$ & Bagtikan & $\begin{array}{l}\text { Tree \& } \\
\text { Shrub }\end{array}$ & $\mathrm{CE}^{1}$ & Endemic \\
\hline Dipterocarpaceae & Shorea contorta Vidal & White Lauan & $\begin{array}{l}\text { Tree \& } \\
\text { Shrub }\end{array}$ & $\mathrm{CE}^{1} \mathrm{VU}^{2}$ & $\begin{array}{c}\text { Phil } \\
\text { Endemic }\end{array}$ \\
\hline
\end{tabular}


ISSN No:-2456-2165

\begin{tabular}{|c|c|c|c|c|c|}
\hline Dipterocarpaceae & Shorea gisok/falciferoides Foxw. & Gisok & $\begin{array}{l}\text { Tree \& } \\
\text { Shrub }\end{array}$ & $\mathrm{CE}^{1} \mathrm{VU}^{2}$ & Endemic \\
\hline Dipterocarpaceae & Shorea negrosensis Foxw. & Red lawaan & $\begin{array}{l}\text { Tree \& } \\
\text { Shrub }\end{array}$ & $\mathrm{CE}^{1} \mathrm{VU}^{2}$ & $\begin{array}{c}\text { Phil } \\
\text { Endemic }\end{array}$ \\
\hline Dipterocarpaceae & Shorea polysperma (Blanco) Merr. & Tangile & $\begin{array}{l}\text { Tree \& } \\
\text { Shrub }\end{array}$ & $\mathrm{CE}^{1} \mathrm{VU}^{2}$ & $\begin{array}{c}\text { Phil } \\
\text { Endemic }\end{array}$ \\
\hline Dipterocarpaceae & 1493hore asp. & Halong-halong & $\begin{array}{l}\text { Tree \& } \\
\text { Shrub }\end{array}$ & & \\
\hline Dipterocarpaceae & Shorea astylosa Foxw. & Yakal & $\begin{array}{l}\text { Tree \& } \\
\text { Shrub } \\
\end{array}$ & $\mathrm{CE}^{1} \mathrm{CE}^{2}$ & \\
\hline Dryopteridaceae & Dryopteris sp. & & Fern & & \\
\hline Ebenaceae & Diospyros philippinensis & Kamagong & $\begin{array}{l}\text { Tree \& } \\
\text { Shrub }\end{array}$ & $\mathrm{VU}^{2}$ & $\begin{array}{c}\text { Phil } \\
\text { Endemic }\end{array}$ \\
\hline Euphorbiaceae & Euphorbiaceae & Marapot & $\begin{array}{l}\text { Tree \& } \\
\text { Shrub }\end{array}$ & & \\
\hline Euphorbiaceae & $\begin{array}{c}\text { Homalanthus populneus (Geiseler) } \\
\text { Pax }\end{array}$ & Balanti & $\begin{array}{l}\text { Tree \& } \\
\text { Shrub }\end{array}$ & $\mathrm{LC}^{1}$ & Endemic \\
\hline Euphorbiaceae & Macaranga bicolor Muell.-Arg. & Hamil-ig & $\begin{array}{l}\text { Tree \& } \\
\text { Shrub }\end{array}$ & $\mathrm{VU}^{1}$ & $\begin{array}{c}\text { Phil } \\
\text { Endemic }\end{array}$ \\
\hline
\end{tabular}

Table 7

\begin{tabular}{|c|c|c|c|c|c|}
\hline Family Name & Scientific Name & $\begin{array}{l}\text { Common } \\
\text { Name }\end{array}$ & $\begin{array}{l}\text { Plant } \\
\text { Habit }\end{array}$ & $\begin{array}{l}\text { Conservation } \\
\text { Status }\end{array}$ & Endemicity \\
\hline Euphorbiaceae & Macaranga gigantifolia Merr. & & $\begin{array}{l}\text { Tree \& } \\
\text { Shrub }\end{array}$ & & \\
\hline Euphorbiaceae & Macaranga hispida (Blume) Müll.Arg. & & $\begin{array}{l}\text { Tree \& } \\
\text { Shrub }\end{array}$ & & \\
\hline Euphorbiaceae & Macaranga sp. & & $\begin{array}{l}\text { Tree \& } \\
\text { Shrub }\end{array}$ & & \\
\hline Euphorbiaceae & Macaranga tanarius (L.) Müll.Arg. & Binunga & $\begin{array}{l}\text { Tree \& } \\
\text { Shrub }\end{array}$ & & \\
\hline Euphorbiaceae & Mallotus cumingii (Müll.Arg.) & Apanang & $\begin{array}{l}\text { Tree \& } \\
\text { Shrub }\end{array}$ & & Endemic \\
\hline Euphorbiaceae & Mallotus sp. & Salimbugaw & $\begin{array}{l}\text { Tree \& } \\
\text { Shrub }\end{array}$ & & \\
\hline Euphorbiaceae & $\begin{array}{l}\text { Melanolepis multiglandulosa (Reinw. Ex } \\
\text { Blume) Rchb.f. \& Zoll. }\end{array}$ & Alim & $\begin{array}{l}\text { Tree \& } \\
\text { Shrub }\end{array}$ & & Native \\
\hline Euphorbiaceae & Euphorbia hirta $\mathrm{L}$ & Tawa-tawa & Herb & & Endemic \\
\hline Fabaceae & Calopogonium sp. & Cover crop & Grass & $\mathrm{LC}^{1}$ & \\
\hline Fabaceae & Centrosema pubescens Benth. & Kodso & Vine & & Introduced \\
\hline Fabaceae & Derris elliptica (Wall.) Benth. & Bagon & Vine & & Endemic \\
\hline Fabaceae & Derris sp. & & Vine & & \\
\hline Fabaceae & Acacia mangium Willd. & Mangium & $\begin{array}{l}\text { Tree \& } \\
\text { Shrub }\end{array}$ & $\mathrm{LC}^{1}$ & Introduced \\
\hline Fabaceae & Afzelia rhomboidea (Blanco) S.Vidal & Tindalo & $\begin{array}{l}\text { Tree \& } \\
\text { Shrub }\end{array}$ & $\mathrm{VU}^{1} \mathrm{E}^{2}$ & Endemic \\
\hline Fabaceae & Bauhinia sp. & Alibangbang & $\begin{array}{l}\text { Tree \& } \\
\text { Shrub }\end{array}$ & & \\
\hline Fabaceae & Dagong (fabaceae with thorns) & & $\begin{array}{l}\text { Tree \& } \\
\text { Shrub }\end{array}$ & & \\
\hline Fabaceae & Erythrina orientalis $\mathrm{L}$. & Dapdap & $\begin{array}{l}\text { Tree \& } \\
\text { Shrub }\end{array}$ & & Introduced \\
\hline Fabaceae & Flemingia sp. & Flamengia & $\begin{array}{l}\text { Tree \& } \\
\text { Shrub }\end{array}$ & & \\
\hline Fabaceae & Leucaena leucocephala (Lam.) de Wit[ & Ipil-ipil & $\begin{array}{l}\text { Tree \& } \\
\text { Shrub }\end{array}$ & & Introduced \\
\hline Fabaceae & Litsea philippinensis Merr. & Bakan & Tree \& & & Phil \\
\hline
\end{tabular}


ISSN No:-2456-2165

\begin{tabular}{|c|c|c|c|c|c|}
\hline & & & Shrub & & Endemic \\
\hline Fabaceae & Ormosia cavalensis & Bahay & $\begin{array}{c}\text { Tree \& } \\
\text { Shrub }\end{array}$ & & Introduced \\
\hline Fabaceae & Paraserianthes falcataria $\mathrm{L}$. & Falcata & $\begin{array}{c}\text { Tree \& } \\
\text { Shrub }\end{array}$ & & Native \\
\hline Fabaceae & Pterocarpus indicus Willd. & Narra & $\begin{array}{c}\text { Tree \& } \\
\text { Shrub }\end{array}$ & $\mathrm{E}^{1} \mathrm{VU}^{2}$ & \\
\hline Fabaceae & Tagum-tagum & $\begin{array}{c}\text { Tagum- } \\
\text { tagum }\end{array}$ & $\begin{array}{c}\text { Tree \& } \\
\text { Shrub }\end{array}$ & & Invasive \\
\hline Fabaceae & Mimosa pigra $\mathrm{L}$. & Sampinit & Vine & & \\
\hline
\end{tabular}

Table 8

\begin{tabular}{|c|c|c|c|c|c|}
\hline Family Name & Scientific Name & $\begin{array}{c}\text { Common } \\
\text { Name }\end{array}$ & Plant Habit & $\begin{array}{c}\text { Conservation } \\
\text { Status } \\
\end{array}$ & Endemicity \\
\hline Fagaceae & Lithocarpus ilanosii & Ulayan & $\begin{array}{l}\text { Tree \& } \\
\text { Shrub }\end{array}$ & & \\
\hline Flagellariaceae & Flagellaria indica $\mathrm{L}$. & Aliwangkai & Vine & & Endemic \\
\hline Gesneriaceae & Aeschynanthus sp. & Lipstick plant & $\begin{array}{l}\text { Tree \& } \\
\text { Shrub }\end{array}$ & & \\
\hline Gleichnaceae & $\begin{array}{l}\text { Dicranopteris linearis (Burm.f.) } \\
\text { Underw. }\end{array}$ & & Fern & & Endemic \\
\hline Hypericaceae & Cratoxylum sumatranum (Jack) Bl. & Pag-uringon & $\begin{array}{l}\text { Tree \& } \\
\text { Shrub }\end{array}$ & $\mathrm{LC}^{1}$ & Endemic \\
\hline Lamiaceae & Gmelina arborea Roxb. & Gmelina & $\begin{array}{l}\text { Tree \& } \\
\text { Shrub }\end{array}$ & & Introduced \\
\hline Lamiaceae & Premna odorata Blanco & Adgaw & $\begin{array}{l}\text { Tree \& } \\
\text { Shrub }\end{array}$ & & Endemic \\
\hline Lamiaceae & $\begin{array}{l}\text { Teijsmanniodendron ahernianum } \\
\text { Merr. }\end{array}$ & Kulipapa & $\begin{array}{l}\text { Tree \& } \\
\text { Shrub }\end{array}$ & & Endemic \\
\hline Lamiaceae & Vitex parviflora Juss. & Tugas & $\begin{array}{l}\text { Tree \& } \\
\text { Shrub }\end{array}$ & $\mathrm{VU}^{1}$ & Endemic \\
\hline Lauraceae & Cinnamomum mercadoi S.Vidal & Kalingag & $\begin{array}{l}\text { Tree \& } \\
\text { Shrub }\end{array}$ & $\mathrm{VU}^{1}$ & indigenous \\
\hline Lecythidaceae & $\begin{array}{c}\text { Petersianthus quadrialatus (Merr.) } \\
\text { Merr. }\end{array}$ & Toog & $\begin{array}{l}\text { Tree \& } \\
\text { Shrub }\end{array}$ & & indigenous \\
\hline Loganiaceae & Fragrae racemosa & Malakape & $\begin{array}{l}\text { Tree \& } \\
\text { Shrub } \\
\end{array}$ & & \\
\hline Malvaceae & Ceiba pentandra (L.) Gaertn. & Gapas & $\begin{array}{l}\text { Tree \& } \\
\text { Shrub }\end{array}$ & & Introduced \\
\hline Malvaceae & Colona serratifolia Cav. & Anilau & $\begin{array}{l}\text { Tree \& } \\
\text { Shrub }\end{array}$ & & \\
\hline Malvaceae & Commersonia bartramia (L.) Merr. & Banitlong & $\begin{array}{l}\text { Tree \& } \\
\text { Shrub }\end{array}$ & & \\
\hline Malvaceae & Diplodiscus paniculatus Turcz. & Balobo & $\begin{array}{l}\text { Tree \& } \\
\text { Shrub }\end{array}$ & $\mathrm{VU}^{1}$ & indigenous \\
\hline Malvaceae & Kleinhovia 1494ospital L. & Bitan-ag & $\begin{array}{l}\text { Tree \& } \\
\text { Shrub }\end{array}$ & & Endemic \\
\hline Malvaceae & Pterospermum sp. & Bayog & $\begin{array}{l}\text { Tree \& } \\
\text { Shrub }\end{array}$ & & \\
\hline Malvaceae & Theobroma sp. & Kakaw-kakaw & $\begin{array}{l}\text { Tree \& } \\
\text { Shrub }\end{array}$ & & \\
\hline Marantaceae & $\begin{array}{c}\text { Donax canniformis (G.Forst.) } \\
\text { K.Schum. }\end{array}$ & Banban & $\begin{array}{l}\text { Tree \& } \\
\text { Shrub }\end{array}$ & & Endemic \\
\hline Marantaceae & Phrynium interruptum & Hagikhik & Herb & & Endemic \\
\hline Marratiaceae & $\begin{array}{c}\text { Angiopteris palmiformis (Cav.) C. } \\
\text { Chr. }\end{array}$ & Giant fern & Fern & & \\
\hline Marratiaceae & Marratia sylvatica Blume & Giant fern & Fern & & \\
\hline Melastomaceae & Dissochaeta sp. & & Tree \& & & \\
\hline
\end{tabular}


ISSN No:-2456-2165

\begin{tabular}{|l|c|l|l|l|}
\hline & & & Shrub & \\
\hline Melastomaceae & Melastoma malabahtricum & Hantutuknaw & $\begin{array}{c}\text { Tree \& } \\
\text { Shrub }\end{array}$ & \\
\hline Melastomaceae & Melastoma sp. & & $\begin{array}{c}\text { Tree \& } \\
\text { Shrub }\end{array}$ & \\
\hline
\end{tabular}

Table 9

\begin{tabular}{|c|c|c|c|c|c|}
\hline Family Name & Scientific Name & Common Name & $\begin{array}{l}\text { Plant } \\
\text { Habit }\end{array}$ & $\begin{array}{c}\text { Conservation } \\
\text { Status }\end{array}$ & Endemicity \\
\hline Meliaceae & Aglaia sp. & Saging sa unggoy & $\begin{array}{l}\text { Tree \& } \\
\text { Shrub }\end{array}$ & & \\
\hline Meliaceae & Chisocheton tetrapetalus Turcz. & Ibo & $\begin{array}{l}\text { Tree \& } \\
\text { Shrub }\end{array}$ & & \\
\hline Meliaceae & $\begin{array}{l}\text { Lansium domesticum (Osbeck) } \\
\text { Sahni \& Bennet }\end{array}$ & Lanzones & $\begin{array}{l}\text { Tree \& } \\
\text { Shrub }\end{array}$ & & Introduced \\
\hline Meliaceae & Swietenia macrophylla King & Mahogany & $\begin{array}{l}\text { Tree \& } \\
\text { Shrub }\end{array}$ & $\mathrm{VU}^{1}$ & Introduced \\
\hline Meliaceae & Toona calantas Merr. \& Rolfe & Lanipga & $\begin{array}{l}\text { Tree \& } \\
\text { Shrub } \\
\end{array}$ & $\mathrm{DD}^{1} \mathrm{VU}^{2}$ & Endemic \\
\hline Minespermaceae & Minespermaceae & Lagtang & Vine & & \\
\hline Moraceae & Artocarpus blancoi Merr. & Antipolo & $\begin{array}{l}\text { Tree \& } \\
\text { Shrub }\end{array}$ & $\mathrm{VU}^{1}$ & $\begin{array}{c}\text { Phil } \\
\text { Endemic }\end{array}$ \\
\hline Moraceae & Artocarpus heterophyllus Lam. & Nangka & $\begin{array}{l}\text { Tree \& } \\
\text { Shrub }\end{array}$ & & Introduced \\
\hline Moraceae & Artocarpus treculianus Elmer & Tugop/Marang dahon & $\begin{array}{l}\text { Tree \& } \\
\text { Shrub }\end{array}$ & $\mathrm{VU}^{1}$ & $\begin{array}{c}\text { Phil } \\
\text { Endemic }\end{array}$ \\
\hline Moraceae & Ficus balete & Balibalete & $\begin{array}{l}\text { Tree \& } \\
\text { Shrub } \\
\end{array}$ & & \\
\hline Moraceae & Ficus heteropoda Miq. & Langas & $\begin{array}{l}\text { Tree \& } \\
\text { Shrub }\end{array}$ & & \\
\hline Moraceae & $\begin{array}{c}\text { Ficus minahassae Tesym. \& De } \\
\text { Vr. }\end{array}$ & Hagimit & $\begin{array}{l}\text { Tree \& } \\
\text { Shrub }\end{array}$ & & \\
\hline Moraceae & Ficus nota & Tubog & $\begin{array}{l}\text { Tree \& } \\
\text { Shrub }\end{array}$ & & $\begin{array}{c}\text { Phil } \\
\text { Endemic }\end{array}$ \\
\hline Moraceae & Ficus odorata (Blanco) Merr. & Hagupit & $\begin{array}{l}\text { Tree \& } \\
\text { Shrub } \\
\end{array}$ & & \\
\hline Moraceae & Ficus pseudopalma Blanco & Niog-niogan & $\begin{array}{l}\text { Tree \& } \\
\text { Shrub }\end{array}$ & & $\begin{array}{c}\text { Phil } \\
\text { Endemic }\end{array}$ \\
\hline Moraceae & Ficus septica Burm.f. & Hawili & $\begin{array}{l}\text { Tree \& } \\
\text { Shrub }\end{array}$ & & Endemic \\
\hline Moraceae & Ficus sp. & Piri & $\begin{array}{l}\text { Tree \& } \\
\text { Shrub }\end{array}$ & & \\
\hline Moraceae & Ficus stipulosa Miq. & Dakit & $\begin{array}{l}\text { Tree \& } \\
\text { Shrub }\end{array}$ & & Endemic \\
\hline Moraceae & Ficus ulmifolia Lam. & Sagusahis & $\begin{array}{l}\text { Tree \& } \\
\text { Shrub }\end{array}$ & $\mathrm{VU}^{1}$ & $\begin{array}{c}\text { Phil } \\
\text { Endemic }\end{array}$ \\
\hline Moraceae & Ficus 1495 cuminate Blume & $\begin{array}{c}\text { Kaw-ot/Tangisang } \\
\text { bayawak }\end{array}$ & $\begin{array}{l}\text { Tree \& } \\
\text { Shrub }\end{array}$ & & Endemic \\
\hline Musaceae & Musa 1495cuminate Colla & Paguha & Herb & $\mathrm{LC}^{1}$ & Native \\
\hline Musaceae & Musa balbisiana Colla & Tundan & Herb & & Native \\
\hline Musaceae & Musa paradisiaca L. & Abaka & Herb & & Introduced \\
\hline Musaceae & Musa sapientum L. & Saging & Herb & & Native \\
\hline Musaceae & Musa sp. & Karnaba & Herb & & \\
\hline
\end{tabular}

Table 10 
ISSN No:-2456-2165

\begin{tabular}{|c|c|c|c|c|c|}
\hline Family Name & Scientific Name & Common Name & $\begin{array}{l}\text { Plant } \\
\text { Habit }\end{array}$ & $\begin{array}{c}\text { Conservation } \\
\text { Status } \\
\end{array}$ & Endemicity \\
\hline Musaceae & Musa sp. & Barobongoran & Herb & & \\
\hline Musaceae & Musa textilis Née & $\begin{array}{c}\text { Wild Abaca / } \\
\text { Laguras }\end{array}$ & Herb & & Native \\
\hline Myricaceae & Myrica javanica Blume & Hindang & $\begin{array}{l}\text { Tree \& } \\
\text { Shrub }\end{array}$ & & \\
\hline Myricaceae & Myrica sp. 1 & Hindang bato & $\begin{array}{l}\text { Tree \& } \\
\text { Shrub }\end{array}$ & & \\
\hline Myricaceae & Myrica sp. 2 & $\begin{array}{c}\text { Hindang } \\
\text { malaavocado }\end{array}$ & $\begin{array}{l}\text { Tree \& } \\
\text { Shrub }\end{array}$ & & \\
\hline Myricaceae & Myrica sp. 3 & Hindang talisay & $\begin{array}{l}\text { Tree \& } \\
\text { Shrub }\end{array}$ & & \\
\hline Myristicaceae & Knema sp. & Banajakaw & $\begin{array}{l}\text { Tree \& } \\
\text { Shrub }\end{array}$ & & \\
\hline Myristicaceae & Myristica philippinensis Gandoger & Duguan & $\begin{array}{l}\text { Tree \& } \\
\text { Shrub }\end{array}$ & $\mathrm{VU}^{1}$ & $\begin{array}{c}\text { Phil } \\
\text { Endemic }\end{array}$ \\
\hline Myrtaceae & Eugenia sp. 1 & Bansilay & $\begin{array}{l}\text { Tree \& } \\
\text { Shrub }\end{array}$ & & \\
\hline Myrtaceae & Eugenia sp. 2 & Sagimsim & $\begin{array}{l}\text { Tree \& } \\
\text { Shrub }\end{array}$ & & \\
\hline Myrtaceae & Myrtaceae & Bansilay & $\begin{array}{l}\text { Tree \& } \\
\text { Shrub }\end{array}$ & & \\
\hline Myrtaceae & Myrtaceae & Sagimsim pula & $\begin{array}{l}\text { Tree \& } \\
\text { Shrub }\end{array}$ & & \\
\hline Myrtaceae & Psidium guajava $\mathrm{L}$. & Bayabas & $\begin{array}{l}\text { Tree \& } \\
\text { Shrub }\end{array}$ & & Introduced \\
\hline Myrtaceae & $\begin{array}{c}\text { Syzygium hutchinsonii (C.B.Robinson) } \\
\text { Merr. }\end{array}$ & Malatambis & $\begin{array}{l}\text { Tree \& } \\
\text { Shrub }\end{array}$ & & $\begin{array}{c}\text { Phil } \\
\text { Endemic }\end{array}$ \\
\hline Myrtaceae & Syzygium sp. & Hantatamsi & $\begin{array}{l}\text { Tree \& } \\
\text { Shrub } \\
\end{array}$ & & \\
\hline Myrtaceae & $\begin{array}{l}\text { Tristaniopsis littoralis (Merr.) Peter } \\
\text { G.Wilson \& J.T.Waterh. }\end{array}$ & Tiga & $\begin{array}{l}\text { Tree \& } \\
\text { Shrub }\end{array}$ & $\mathrm{VU}^{1} \mathrm{VU}^{2}$ & $\begin{array}{c}\text { Phil } \\
\text { Endemic } \\
\end{array}$ \\
\hline Nephrolepidaceae & Nephrolepis biserrata (Sw.) Schott & Lukdo & Fern & & Endemic \\
\hline Nephrolepidaceae & Nephrolepis cordata & & Fern & & Native \\
\hline Orchidaceae & Dendrobium sp. & Ground orchid & Herb & & \\
\hline Orchidaceae & Liparis sp. & & Herb & & \\
\hline Orchidaceae & Orchidaceae (gagmay dahon red) & & Herb & & \\
\hline Orchidaceae & Spathoglottis plicata Blume & Lubi lubi & Herb & & Endemic \\
\hline Osmundaceae & Osmunda banksifollia & & Fern & & \\
\hline Oxalidaceae & Averrhoa bilimbi $\mathrm{L}$. & Iba & $\begin{array}{l}\text { Tree \& } \\
\text { Shrub }\end{array}$ & & Introduced \\
\hline Pandanaceae & Freycinetia multiflora Merr. & & Vine & & \\
\hline Pandanaceae & Pandanus affinis & & Herb & & \\
\hline
\end{tabular}

Table 11

\begin{tabular}{|c|c|c|c|c|c|}
\hline Family Name & Scientific Name & $\begin{array}{c}\text { Common } \\
\text { Name }\end{array}$ & Plant Habit & $\begin{array}{c}\text { Conservation } \\
\text { Status }\end{array}$ & Endemicity \\
\hline Pandanaceae & Pandanus copelandii Merr. & Baliw & Herb & & Native \\
\hline Pandanaceae & Pandanus odoratissimus (Kewda) & & Herb & & Native \\
\hline Phyllanthaceae & Antidesma bunius (L.) Spreng. & Bignay & $\begin{array}{c}\text { Tree \& } \\
\text { Shrub }\end{array}$ & & \\
\hline Phyllanthaceae & Breynia sp. & Salampaturog & $\begin{array}{c}\text { Tree \& } \\
\text { Shrub }\end{array}$ & LC $^{1}$ & \\
\hline Phyllanthaceae & Glochidion sp. & Bonot-bonot & $\begin{array}{c}\text { Tree \& } \\
\text { Shrub }\end{array}$ & & \\
\hline
\end{tabular}


ISSN No:-2456-2165

\begin{tabular}{|c|c|c|c|c|c|}
\hline Piperaceae & Piper aduncum L. & Loblobay & $\begin{array}{l}\text { Tree \& } \\
\text { Shrub }\end{array}$ & & Introduced \\
\hline Poaceae & $\begin{array}{l}\text { Bambusa blumeana Schult. \& } \\
\text { Schult.f. }\end{array}$ & Bokawe & Grass & & Endemic \\
\hline Poaceae & Bambusa sp. & & Grass & & \\
\hline Poaceae & Bambusa sp. (pantahi) & & Grass & & \\
\hline Poaceae & $\begin{array}{c}\text { Imperata 1497rabical497cal (L.) } \\
\text { P.Beauv. }\end{array}$ & Cogon & Grass & & Endemic \\
\hline Poaceae & Paspalum conjugatum P.J.Bergius & Carabao grass & Grass & & Endemic \\
\hline Poaceae & Saccharrum spontaneum L. & Bugang & Grass & & Introduced \\
\hline Polypodiaceae & \multicolumn{2}{|c|}{ Drynaria quercifolia (L.) Hovenkamp \& S. Linds. } & Fern & & Native \\
\hline Polypodiaceae & Microsorum sp. & & Fern & & \\
\hline Pteridaceae & Adiantum sp. & & Fern & & \\
\hline Pteridaceae & $\begin{array}{l}\text { Antrophyum reticulatum (G. Forst.) } \\
\text { Kaulf. }\end{array}$ & & Fern & & \\
\hline Raflessiaceae & Rafflessia mixta & & Herb & $\mathrm{CE}^{2}$ & $\begin{array}{c}\text { Phil } \\
\text { Endemic }\end{array}$ \\
\hline Raflessiaceae & Scleria scloribata & Daat & Grass & & \\
\hline Ranunculaceae & Clematis smilacifolia $\mathrm{L}$. & & Vine & & Native \\
\hline Rhamnaceae & Ziziphus sp. & & $\begin{array}{l}\text { Tree \& } \\
\text { Shrub }\end{array}$ & & \\
\hline Rubiaceae & Hydnophytum formicarum Jack & Ant plant & Herb & & Native \\
\hline Rubiaceae & Coffee 1497rabica L. & Kape & $\begin{array}{l}\text { Tree \& } \\
\text { Shrub }\end{array}$ & & Introduced \\
\hline Rubiaceae & Morinda citrifolia $\mathrm{L}$. & Nino & $\begin{array}{l}\text { Tree \& } \\
\text { Shrub }\end{array}$ & & Native \\
\hline Rubiaceae & Mussaenda sp. & Talatawa & $\begin{array}{l}\text { Tree \& } \\
\text { Shrub }\end{array}$ & & \\
\hline Rubiaceae & Nauclea occidentalis & Bangkal & $\begin{array}{l}\text { Tree \& } \\
\text { Shrub }\end{array}$ & & Endemic \\
\hline Rubiaceae & $\begin{array}{c}\text { Neonauclea formicaria (Elmer) } \\
\text { Merr. }\end{array}$ & Hambabalod & $\begin{array}{l}\text { Tree \& } \\
\text { Shrub }\end{array}$ & & \\
\hline
\end{tabular}

Table 12

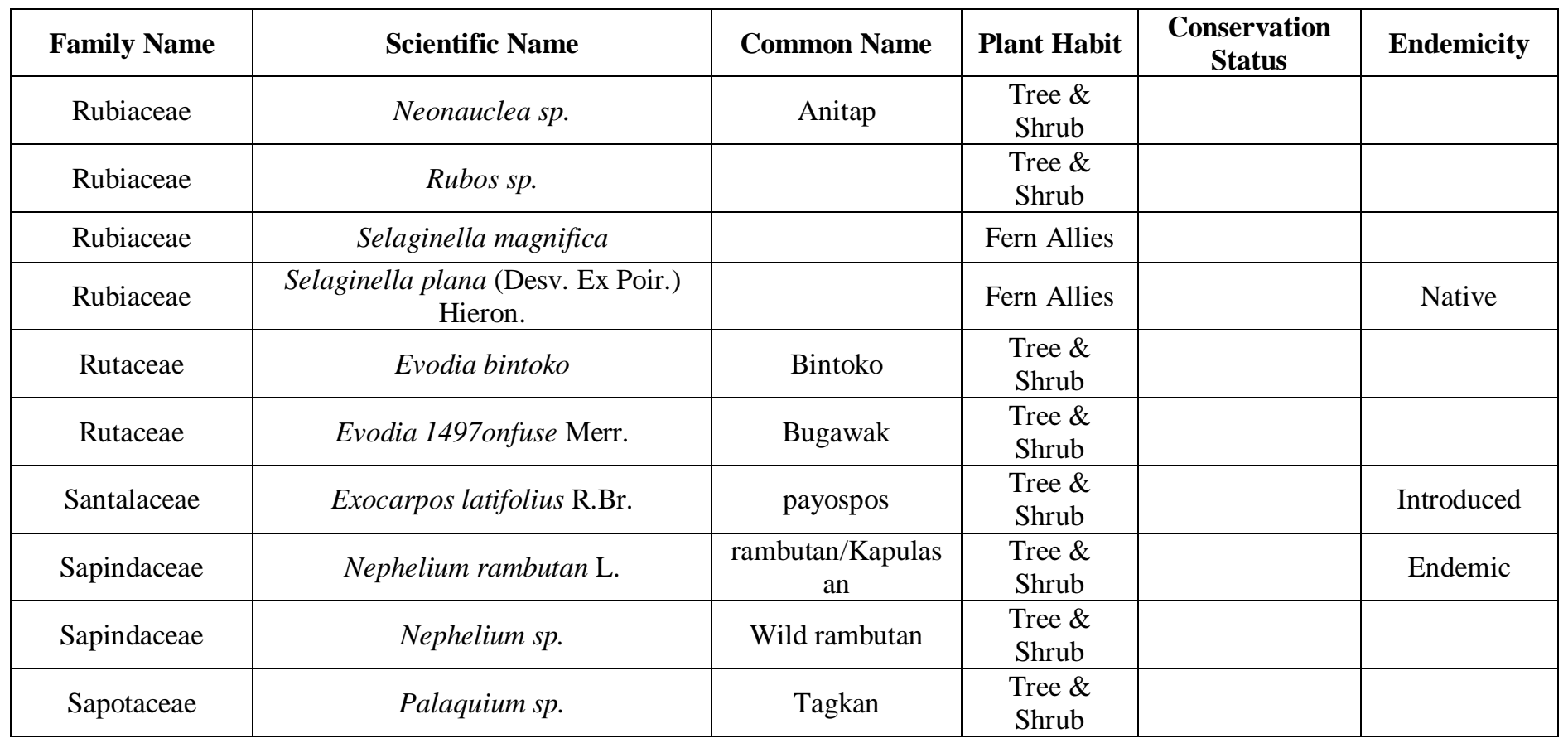


ISSN No:-2456-2165

\begin{tabular}{|c|c|c|c|c|c|}
\hline Sapotaceae & Pouteria velutina Elmer & Wakatan & $\begin{array}{l}\text { Tree \& } \\
\text { Shrub }\end{array}$ & & \\
\hline Schizaeaceae & Lygodium circinatum (Burm. F.) Sw. & & Fern & & Native \\
\hline Smilaceae & Smilax aspera $\mathrm{L}$. & Smilax aspera & Vine & & Introduced \\
\hline Smilaceae & Smilax bracteata C.Presl & Banag & Vine & & \\
\hline Sterculiaceae & Sterculia glavifera & Uos & $\begin{array}{l}\text { Tree \& } \\
\text { Shrub }\end{array}$ & & \\
\hline Tectariaceae & Tectaria decurrens (C. Presl) Copel. & & Fern & & \\
\hline Thelypteridaceae & Christella parasitica (L.) Holttum & & Fern & & \\
\hline Urticaceae & $\begin{array}{c}\text { Poikilospermum suaveolens (Blume) } \\
\text { Merr. }\end{array}$ & Hanopol & Herb & & \\
\hline Urticaceae & Leucosyke capitellata Wedd. & Alagasi & $\begin{array}{l}\text { Tree \& } \\
\text { Shrub }\end{array}$ & & \\
\hline Urticaceae & $\begin{array}{c}\text { Musanga cecropioides } \mathrm{R} . \mathrm{Br} . \& \\
\text { Tedlie }\end{array}$ & & $\begin{array}{l}\text { Tree \& } \\
\text { Shrub }\end{array}$ & & Introduced \\
\hline Urticaceae & $\begin{array}{c}\text { Pipturus arborescens (Link) C.B. } \\
\text { Rob. }\end{array}$ & Handadamay & $\begin{array}{l}\text { Tree \& } \\
\text { Shrub }\end{array}$ & & \\
\hline Urticaceae & Urtica dioica $\mathrm{L}$. & Sagay/Alingatong & $\begin{array}{l}\text { Tree \& } \\
\text { Shrub }\end{array}$ & & Introduced \\
\hline Urticaceae & Urticaceae & Balansaging & $\begin{array}{l}\text { Tree \& } \\
\text { Shrub }\end{array}$ & & \\
\hline
\end{tabular}

Table 13

\begin{tabular}{|c|c|c|c|c|c|}
\hline Family Name & Scientific Name & Common Name & Plant Habit & $\begin{array}{c}\text { Conservation } \\
\text { Status }\end{array}$ & Endemicity \\
\hline Verbenaceae & Lantana camara L. & Baho-baho & Tree \& Shrub & & Introduced \\
\hline Verbenaceae & $\begin{array}{c}\text { Stachytarpheta jamaicensis (L.) } \\
\text { Vahl }\end{array}$ & Kanding-kanding & Tree \& Shrub & & \\
\hline Vitaceae & Tetrastigma sp. & & Vine & & \\
\hline Vitaceae & Leea aculeata Blume ex Spreng. & Amamali & Tree \& Shrub & & Endemic \\
\hline Zingeberaceae & Alpinia haenkei C.Presl & Pinoon & Herb & & \\
\hline Zingeberaceae & Alpinia rufa (C.Presl) Náves & Bagonbon & Herb & & \\
\hline Unidentified & & Alalibabaw & Tree \& Shrub & & \\
\hline Unidentified & & Alibobot & Tree \& Shrub & & \\
\hline Unidentified & & Alipayas & Tree \& Shrub & & \\
\hline Unidentified & & Ando & Tree \& Shrub & & \\
\hline Unidentified & & Aragpange & Tree \& Shrub & & \\
\hline Unidentified & & Atibangalan & Palm & & \\
\hline Unidentified & & Atulob & Tree \& Shrub & & \\
\hline Unidentified & & Baga-baga & Tree \& Shrub & & \\
\hline Unidentified & & Bagkangay & Tree \& Shrub & & \\
\hline Unidentified & & Baje & Tree \& Shrub & & \\
\hline Unidentified & & Bali-bali & Herb & & \\
\hline Unidentified & & Balitadhan & Herb & & \\
\hline
\end{tabular}


ISSN No:-2456-2165

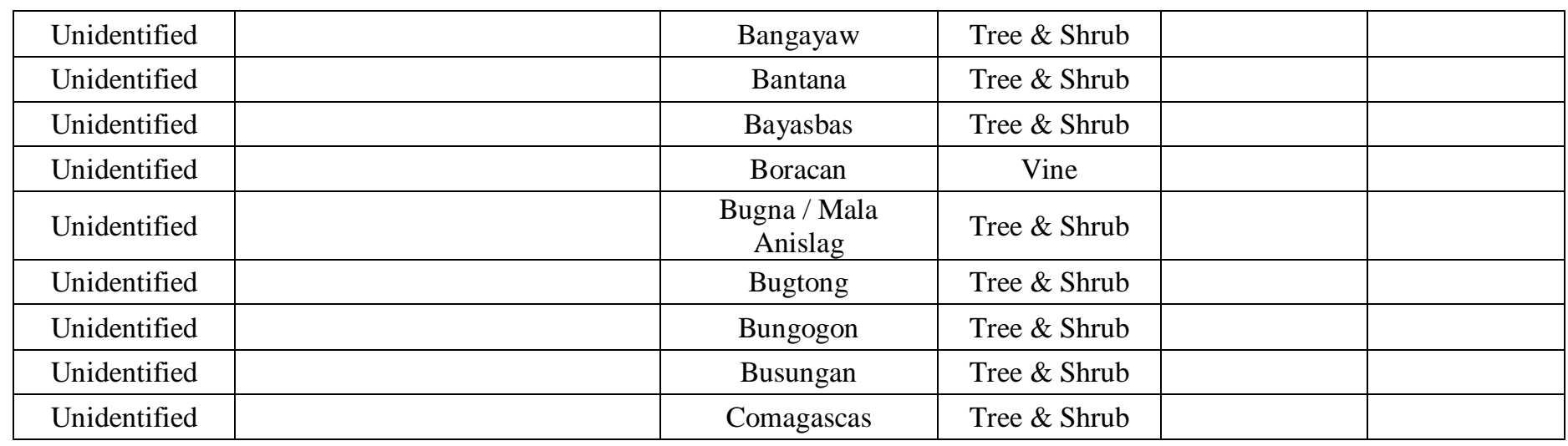

Table 14

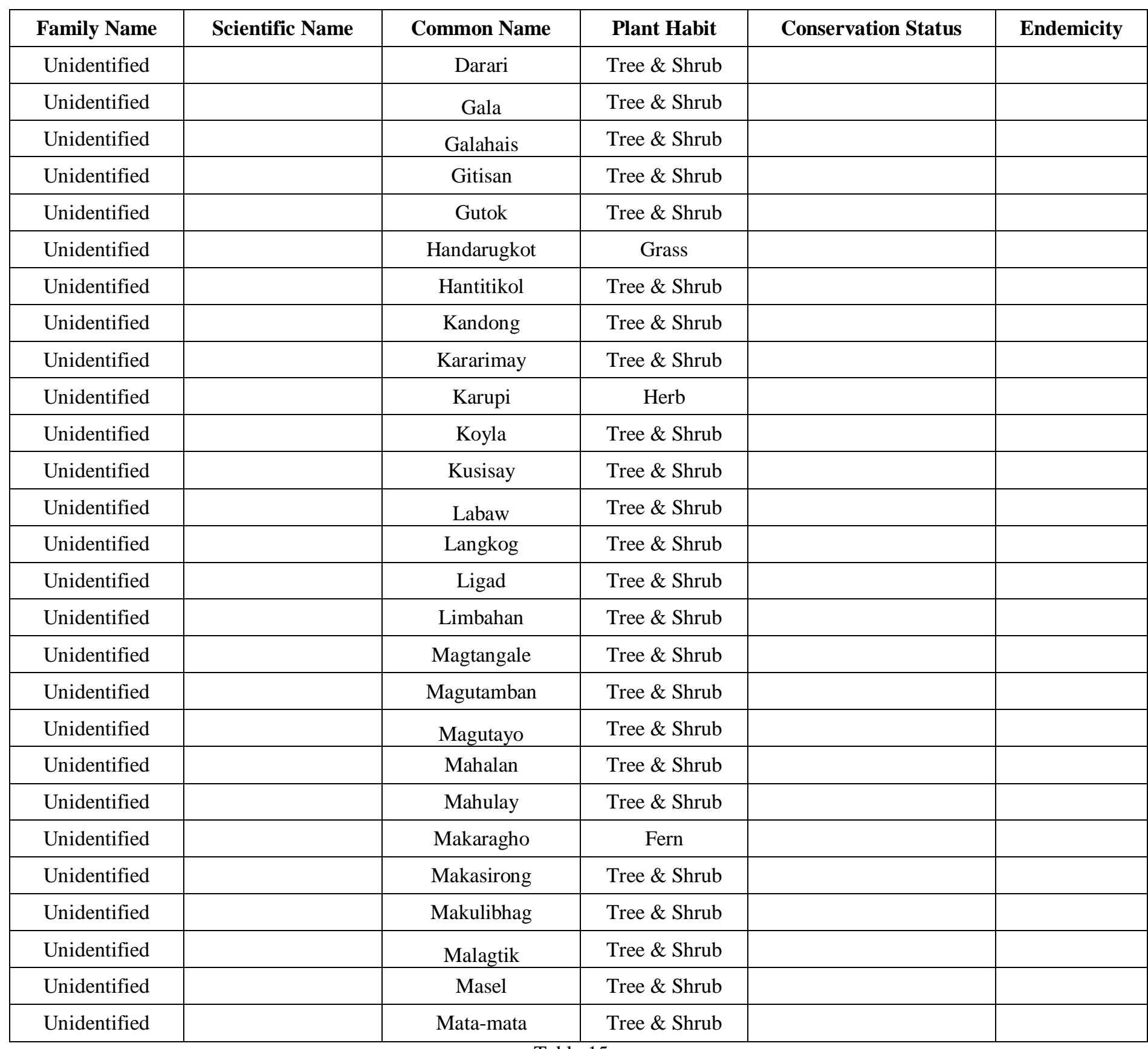


ISSN No:-2456-2165

\begin{tabular}{|c|c|c|c|c|c|}
\hline Family Name & Scientific Name & Common Name & Plant Habit & Conservation Status & Endemicity \\
\hline Unidentified & & Minutay & Tree \& Shrub & & \\
\hline Unidentified & & Parang-parang & Tree \& Shrub & & \\
\hline Unidentified & & Patagon & Tree \& Shrub & & \\
\hline Unidentified & & Pipi & Tree \& Shrub & & \\
\hline Unidentified & & Puyuhon & Tree \& Shrub & & \\
\hline Unidentified & & Sampapad-on & Vine & & \\
\hline Unidentified & & Sibaw & Tree \& Shrub & & \\
\hline Unidentified & & Sukab & Tree \& Shrub & & \\
\hline Unidentified & & Taramag & Palm & & \\
\hline Unidentified & & Tawin-tawin & Tree \& Shrub & & \\
\hline Unidentified & & Ulos & Tree \& Shrub & & \\
\hline Unidentified & & Unidentified fern & Fern & & \\
\hline
\end{tabular}

Note: For conservation status $\left({ }^{1}\right)$ IUCN and $\left({ }^{2}\right)$ for DAO 2017-11. Critically Endangered (CE), Endangered $€$, Vulnerable (VU), Other Threatened Species (OST), Least Concern (LC) and Data Deficient (DD)

Table 16 